\title{
Cameroon's Logging Industry: Structure, Economic Importance and Effects of Devaluation
}

\section{Richard Eba'a Atyi, Tropenbos Cameroon Programme}

CIFOR in collaboration with the Tropenbos Foundation and The Tropenbos Cameroon Programme
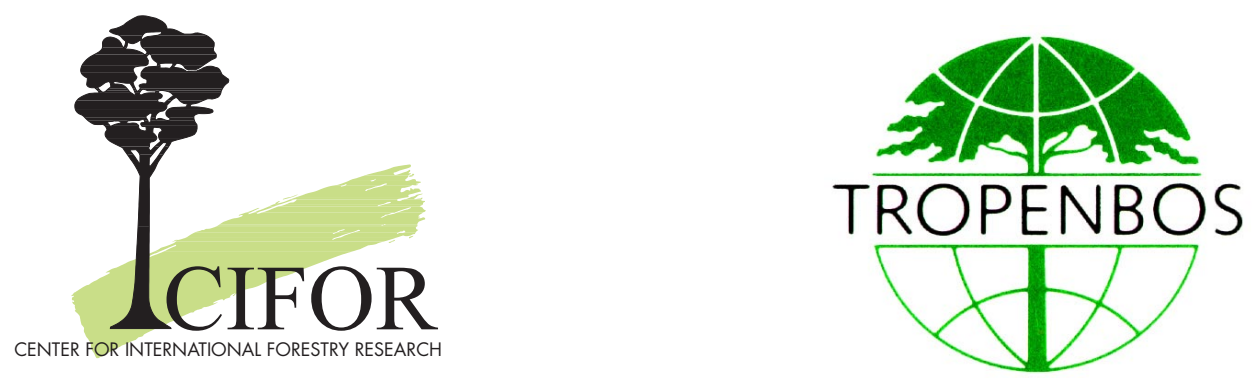

CENTER FOR INTERNATIONAL FORESTRY RESEARCH

office address: Jalan CIFOR, Situ Gede, Sindangbarang, Bogor 16680, Indonesia mailing address: P.O. Box 6596 JKPWB, Jakarta 10065, Indonesia

tel.: +62 (251) 622622 fax: +62 (251) 622100

email: cifor@cgnet.com

$W W W$ : http://www.cgiar.org/cifor 


\section{The CGIAR System}

The Consultative Group on International Agricultural Research (CGIAR) is an informal association of 41 public and private sector donors that supports a network of sixteen international agricultural research institutes, CIFOR being the newest of these. The Group was established in 1971. The CGIAR Centers are part of a global agricultural research system which endeavour to apply international scientific capacity to solution of the problems of the world's disadvantaged people.

\section{CIFOR}

CIFOR was established under the CGIAR system in response to global concerns about the social, environmental and economic consequences of loss and degradation of forests. It operates through a series of highly decentralised partnerships with key institutions and/or individuals throughout the developing and industrialised worlds. The nature and duration of these partnerships are determined by the specific research problems being addressed. This research agenda is under constant review and is subject to change as the partners recognise new opportunities and problems. 


\section{CONTENTS}

List of Acronyms

Preface iii

Summary 1

INTRODUCTION

Study objectives $\quad 3$

$\begin{array}{lr}\text { Methodology } & 4\end{array}$

STRUCTURE OF THE LOGGING INDUSTRY IN CAMEROON

Administrative and legal framework $\quad 5$

$\begin{array}{ll}\text { Distribution of logging enterprises } & 6\end{array}$

Structure and development of the logging industry
Ownership of logging enterprises

$\begin{array}{ll}\text { Industrial log production } & 9\end{array}$

Primary processing capacity $\quad 10$

The market for Cameroon timber products $\quad 11$

IMPORTANCE OF THE LOGGING INDUSTRY IN THE CAMEROON

NATIONAL ECONOMY

Contribution to the balance of payments 13

Contibution to national employment 13

Contribution to Gross National Product and government revenues 14

THE CAMEROON LOGGING INDUSTRY AND THE DEVALUATION OF

\section{THE CFA FRANC}

The CFA franc

Economic crisis in Cameroon $\quad 15$

$\begin{array}{lr}\text { Structural adjustment in Cameroon } & 15\end{array}$

$\begin{array}{ll}\text { Devaluation } & 16\end{array}$

The effects of devaluation on the Cameroon logging industry 16

General aspects of structural adjustment and forest resource management 16

$\begin{array}{ll}\text { Structure of the logging industry } & 17\end{array}$

$\begin{array}{ll}\text { Forest resources } & 17\end{array}$

CONCLUSIONS AND RECOMMENDATIONS 21

REFERENCES 22

ANNEXES

Annex 1: Active logging enterprises of Cameroon 24

Annex 2: Field survey questionnaire $\quad 29$

Annex 3: List of surveyors (students) and supervisors by Province 33

Annex 4: Logging enterprises in the sample 33

Annex 5: Enterprises comprising timber processing units in Cameroon 35

Annex 6: Enterprises involved in timber harvesting in Cameroon
for the fiscal year 1995/96

Annex 7: Timber product exporting enterprises of Cameroon 39 


\section{LIST OF ACRONYMS}

$\begin{array}{ll}\text { CFA: } & \text { Communauté Financiaire d'Afrique } \\ \text { CIFOR: } & \text { Center for International Forestry Research } \\ \text { IMF: } & \text { International Monetary Fund } \\ \text { MINDIC: } & \text { Ministry of Industrial and Commercial Development } \\ \text { MINEF: } & \text { Ministry of Environment and Forestry } \\ \text { ONADEF: } & \text { Office National de Developpement des Forêts } \\ \text { SAP: } & \text { Structural Adjustment Policy } \\ \text { TCP: } & \text { Tropenbos Cameroon Programme } \\ \text { USD: } & \text { United States Dollar } \\ \text { WB: } & \text { World Bank }\end{array}$


This document presents the results of a study conducted in Cameroon between July 1996 and August 1997. The study was the result of a discussion between Dr. Dennis P. Dykstra, Deputy Director General for Research at CIFOR and the author on Cameroon's forestry sector during the IUFRO XX World Congress at Tampere, Finland, in August 1995. This discussion led to the research which was carried out under the sponsorship of CIFOR and the Tropenbos Foundation.

The study aims to improve the available knowledge about Cameroon's forestry sector and its recent development. Cameroon is currently one of the most important producer countries of tropical timber in Africa, but data on the forestry sector are disorganised and incomplete. My intention was to contribute to the improve ment of this situation.

An important part of this report is devoted to a quantitative description of the logging industry. The importance of the logging industry for the economy of Cameroon is also highlighted. The economic life of Cameroon has been affected significantly over the last few years by a structural adjustment policy (SAP) proposed by the World Bank. Consequently I also examine the effects of one of the most spectacular measures of SAP on the logging industry, namely, the devaluation of the CFA franc. I especially consider whether the goal of sustainable forest management has been affected by the devaluation of the CFA currency. Discussions on the devaluation of the CFA franc and the logging industry constitute the other important part of this report.

A number of constraints limited the scope of this study to industrial logging and thus it does not consider the whole forestry sector. It also does not examine all SAP measures, but focuses only on the devaluation of the CFA franc.
This work would not have been possible without the help of many people, to whom I express my deep gratitude. In particular, I would like to thank Dr. Dennis P. Dykstra of CIFOR who not only made the necessary arrangements to provide research funding but also proided me with scientific advice.

I also give special thanks to the Director of the Tropenbos Foundation, Mr. Erik Lammerts van Bueren and the management team of the Tropenbos Cameroo Programme, namely, Mr. Wim van Driel, the Programme team leader, and his counterparts Dr. Oscar Eyog Matig and Mr. Jean Paul Tsimi Mendouga. They provided me with the necessary facilities.

I am deeply indebted to Mr. Bram Filius of the Forestry Department of the Wageningen Agricultural University for his scientific support. My gratitude goes to him.

I received kind assistance from a number of colleagues of the Tropenbos Cameroon Programme who reviewed the draft report and suggested improvements of both the format and the contents. These colleagues were Nere Onguene Awana, Charles Bongjoh, Gerard Hazeu and Barend van Gemerden; my thanks go to them.

Finally, I acknowledge the precious help that came from the Tropenbos Cameroon supporting staff, particularly, Edouard Essiane Mendoula who assisted me in every step of the study and Alloys Aristide Ntonga Diady who contributed to improvement the format of the last draft. 


\title{
CAMEROON'S LOGGING INDUSTRY: STRUCTURE, ECONOMIC IMPORTANCE AND EFFECTS OF DEVALUATION
}

\author{
Richard Eba'a Atyi
}

\begin{abstract}
Summary
The current study was conducted in Cameroon from July 1996 to June 1997. In general, it aims to describe the current structure of the Cameroon logging industry, assess its importance within Cameroon's economy, and analyse recent development which the industry has experienced since the devaluation of the CFA franc in January 1994.

Study methods consisted mainly of carrying out a structured survey of logging enterprises based on a trialled, written questionnaire, reviewing existing documentation within the forestry administration and timber exporting organisations, and conducting an elementary statistical analysis of the information gathered.
\end{abstract}

The main outcomes and conclusions of the study are:

- Head offices of industrial logging enterprises are located in six provinces of Cameroon (out of ten) but logging sites are found in only five provinces. One province, the East province, produces 57\% (in terms of volume) of the logs in Cameroon. In contrast about $83 \%$ of logging enterprises have their head offices in the Littoral and the Centre provinces, where there is adequate communication infrastructure but is far from the resource.

- Timber harvesting is conducted in Cameroon by private enterprises owned by Cameroon nationals as well as foreign investors. However, the characteristics of these enterprises differ substantially based on the nationality of owners (nationals versus foreigners).

- Cameroon Nationals own the largest number of enterprises $(70 \%$ of the total number of accredited enterprises). However, their involvement in logging has developed only recently and can be related to the start of the economic crisis in 1986/87. Before the crisis, Cameroon nationals owned 29\% of all accredited logging enterprises. Since then, the proportion of logging enterprises owned by nationals has increased to reach $90 \%$ in 1996.

- Log production in Cameroon is currently about $2800000 \mathrm{~m}^{3}$ per year. Of this, foreign-owned companies produce $63 \%$, while nationals and enterprises of mixed capital produce $36 \%$ and $1 \%$ respectively.

- There are 60 log processing units in Cameroon with an aggregate capacity of $1988100 \mathrm{~m}^{3}$ of raw logs. These include sawmills as well as veneer and plywood factories. The East province has the biggest log processing capacity ( $42 \%$ of the total). Foreign investors own the major share of log processing capacity. The actual volume of logs processed in Cameroon is estimated to be about $1550525 \mathrm{~m}^{3}$ representing $55.3 \%$ of the total production. This actual volume is thus $78 \%$ of the theoretical nominal capacity, and is below the nation al policy target.

- During the fiscal year 1995/96, Cameroon exported $1254407 \mathrm{~m}^{3}$ of logs $236339 \mathrm{~m}^{3}$ of lumber and about $35000 \mathrm{~m}^{3}$ of veneer and plywood which amount to an estimated $1984612 \mathrm{~m}^{3}$ in log equiv alent.

- The export market consumes about $71 \%$ of Cameroon's timber products.

- Foreign investors control two-thirds of the export market for timber products from Cameroon.

- The logging industry accounts for about $20 \%$ of the total export revenues of Cameroon, and provides direct employment of about 33000 jobs. However, these are mostly of low educational levels. Foreign investors tend to hire foreigners as executive staff.

- Timber harvesting contributes about $6.7 \%$ to the Gross National Product (GNP) of Cameroon based on statistics of the fiscal year 1995/96. This contribution has increased steadily from $3.5 \%$ in $1990 / 91$. During the same fiscal year the contribution to the government budget was about 29 billion CFA francs. 
- The devaluation of the CFA franc seems to have made the logging industry more attractive to the business community of Cameroon. The number of enterprises entering the industry increased by more than $80 \%$ during the fiscal year that followed the devaluation.

- A year after devaluation, the timber harvest in terms of volume had increased by about $34 \%$, and the trend continued over the next two years.

- Timber product exports have increased by about $80 \%$ since the devaluation of the CFA franc.

- The area of forest land opened for logging annually has increased substantially in Cameroon each of the last five years. However, it is difficult to link the increase with the CFA franc devaluation because the trend began before the devaluation.
- The number of timber species harvested and exported has increased since devaluation. Correspondingly, it can be assumed that a higher volume is now harvested per unit area from Cameroon's forests.

- It appears that, the pressure on forest resources has increased since the devaluation. However it is difficult to separate the effect of devaluation from the effects of other reforms that have occurred in the Cameroon forestry sector recently. In addition, it is difficult to conclude that the current level of timber harvesting per hectare is a threat to the sustainability of the forest. However, the total area opened for logging annually is potentially a threat to sustainable forest management. 


\section{INTRODUCTION}

The forest cover of Cameroon consists of about 22.5 million hectares of closed forests. Of these, productive forests on drained land are estimated to cover 17.5 million hectares while the extent of very degraded and swampy forests are 4.5 and 0.5 million hectares respectively (Côté 1993). With these forest resources, Cameroon now plays a leading role in tropical timber production in Africa.

Because of poor road systems, logging was not an attractive business until the mid-1980s. Only a few logging companies, mostly owned by foreigners, were operating during that period. The country received hard currency mainly from the export of oil and agricultural products such as cocoa, coffee and cotton. Timber played a less important role for the national economy and, as a result, timber resources were preserved.

In 1986 and 1987, prices of agricultural products fell sharply while oil production also dropped considerably. Consequently, Cameroon suffered a severe economic crisis. Because prices of timber products were more stable during the same period, the relative importance of the forestry sector in the national economy rose progressively. Furthermore, in an effort to put the economy back on track, Cameroon decision makers adopted a Structural Adjustment Policy (SAP) which included the devaluation of the CFA franc, a regional currency used by most French-speaking countries of west and central Africa including Cameroon. This made logging even more appealing for the business community. At the same time, roads were improved gradually, making logging a more attractive business. All these developments have increased concerns about unsustainable forest exploitation in Cameroon over recent years (Horta 1992; Verhagen and Enthoven 1993; Toornstra et al. 1994).

Unfortunately, detailed information describing the structure and evolution of the Cameroon logging industry is often deficient. Some organisations and individuals still use data that are more than 20 years old; others make rough estimates which vary according to their perceptions. Lack of reliable and up-to-date figures can have various negative consequences as policy designers may underestimate the current importance of the forestry sector, or advocacy groups may be tempted to fabricate subjective statistics.

The study embodied in this report intends to provide detailed information on Cameroon's logging industry based on a systematic data collection and analyses. It concentrates on the description of the structure of the logging industry in Cameroon and its evolution under recent changes of the economic context.

\section{Study Objectives}

The overall objective of the study was to provide an insight into the economic characteristics of the Cameroon logging industry, its place within the national economy and its evolution over the last 10 years (especially following the devaluation of the CFA franc in 1994). More specific objectives were to:

- describe the current structure of the Cameroon logging industry and its development;

- evaluate the contribution of the logging industry to macroeconomic indicators of Cameroon;

- assess the impact of the devaluation of the CFA franc on the structure and development of the logging industry; and

- assess the impact of structural adjustment measures (using the devaluation of the CFA franc as a proxy) on forest resources, especially with respect to the goal of sustainable management of these resources.

It is important to note that the study does not analyse the entire forestry sector, but is limited to the logging industry including log harvesting and primary processing of timber products. Some aspects of the sector as a whole are discussed briefly. Similarly it does not consider the entire package of SAP measures, solely the devaluation of the CFA franc. The following questions were addressed in this study.

- What is the structure of the Cameroon logging industry in terms of the number of enterprises, their size and their ownership?

- What is the current structure of the processing subsector in terms of number, capacity, and quality of processing units?

- What is the structure of the timber product market in Cameroon?

- What is the nature of employment (quantity and quality) provided by the logging industry in Cameroon? 
- What is the contribution of the logging industry to government revenues, Gross Domestic Product (GDP) and balance of payments?

- How has the structure of the logging industry changed over time and especially in the wake of the 1994 CFA franc devaluation?

- How has the devaluation of the CFA franc affected the quality and quantity of timber products harvested from Cameroon forests?

- Are the new trends in forest exploitation less compatible with the goal of sustainability?

\section{Methodology}

The study, which covered 12 months from the first of July 1996, is based mainly on existing documentation and a structured survey using a written questionnaire.

The documentation study was undertaken mainly at the department of forestry of the Ministry of Environment and Forestry (MINEF) in Yaoundé. The aim was to acquire a general understanding of the logging industry in Cameroon. The information obtained consisted of administrative procedures and regulations governing the logging industry, as well as the names of all accredited logging enterprises, their accreditation dates, status of activity (active or inactive) and location of all active logging enterprises operating in the country (Annex 1). An exhaustive documentation survey was also conducted at every seaport to investigate export activities.
A questionnaire was designed and trialled with employees of logging companies around Kribi where the main offices of the Tropenbos Cameroon Programme are located. This step resulted in the adoption of the final format of the questionnaire (Annex 2).

The field survey was carried out the by 12 students under the supervision of 6 regional forestry officers of MINEF (Annex 3). The students had the responsibility of collecting information from logging enterprise staff members and writing short reports. The supervisors, who had better knowledge of the field, introduced the students to appropriate sources of information. The field survey involved only active logging enterprises (220 in total). However only 82 companies(three of which were discarded as special cases because they appeared to be outliers) gave meaningful and interpretable answers to the questionnaire (Annex 4). The survey focused on ownership, history, structure, personnel, production capacity and commercial activities of the enterprises.

Preliminary analysis of field data from the questionnaire enabled preliminary conclusions to be drawn and gaps to be identified where further information was needed by additional field work. As it became apparent that the size of enterprises as well as management objectives and style varied with the nationality of entrepreneurs, the sample was stratified into three categories: 1) enterprises owned by Cameroon nationals; 2)enterprises owned by foreign investors; and 3 ) enterprises of mixed capital (joint venture).

Additional data were gathered as necessary followed by analysis to draw final conclusions. 


\section{STRUCTURE OF THE LOGGING INDUSTRY IN CAMEROON}

\section{Administrative and Legal Framework}

Although a number of other ministries are involved in the functioning of the forestry sector, the main ministerial department responsible for designing and implementing forestry policy in Cameroon is the Ministry of Environment and Finance (MINEF). In addition to the central offices located in Yaoundé with authority extending over the national territory, MINEF has provincial and divisional offices in charge of implementing forestry policy and supervising forestry activities in their respective jurisdictions. ${ }^{1}$ These decentralised services of MINEF follow up and control logging activities in the field. However, MINEF also has an executing agency, the National Office for Forestry Development (ONADEF), which conducts more technical tasks as required by the ministry (e.g., artificial forest regeneration, forestry inventory).

Two main official documents define the administrative and legal framework within which logging occurs in Cameroon. These documents are the Forestry Law No. 94/01 of 20 January 1994 (Government of Cameroon 1994) and its Decree of Application No. 95/531/PM of 23 August 1995 (Government of Cameroon 1995). The Law first defines different types of forests and their respective ownership. In general it categorises the national forest estate into permanent forest estate and non-permanent forest estate. All permanent forests are under state (or sometimes local council) ownership and cannot be converted to land uses other than forests. In contrast, forests of the non-permanent forest estate belong to the national community and can be converted to other forms of land use. However, tracts of land within the non-permanent forest estate can be set aside to produce forest goods for the local communities (community forests) with a more or less permanent status.

In accordance with these two documents, logging activities in the field are regulated by two preliminary administrative steps: an official accreditation in the logging profession and the acquisition of exploitation rights.

Cameroon nationals, as well as foreign entrepreneurs registered in Cameroon, can apply for accreditation to the logging profession. An official accreditation is obtained from MINEF. Interested persons or companies submit an application file which includes official identification of the company and proof of its financial as well as technical capabilities. Before the accreditation is issued by the Minister in charge of forestry, the file is examined by a technical committee made up of eight senior technical officers of MINEF. The technical committee meets twice a year under the chairmanship of the Minister.

Once accreditation is obtained, the entrepreneur is qualified to apply for logging rights. Two types of logging rights can be granted by MINEF.

- Sales of standing volumes (ventes de coupe) which can be small tracts of land (no more than $2500 \mathrm{ha}$ ) or a given volume of standing timber. Sales of standing volumes within both the permanent and non-permanent forest estates can be granted only to Cameroon nationals. Cameroon nationals thereby have easier access to timber resources than foreign investors.

- Concessions are granted to both foreigners and Cameroon nationals for 15 years. Concessions are bigger tracts of forest land covering up to 200000 ha within the permanent forest estate. It is mandatory to draw up a management plan within the first three years of the exploitation contract before any logging can take place in the concession.

The two types of rights are granted after advertisingand competitive bidding from interested loggers.

It should be noted that the framework described here is still in its very early phase of implementation. This implementation started in January 1994 with the adoption of the Forestry Law which waited until August 1995 for its decree of application to be signed. Moreover, the Zoning Plan, which defines the boundaries of the logging concessions on the map, was officially approved by the Prime Minister only in 1996. All this means that, when the current study was being conducted, the logging industry in Cameroon was in a transitional phase. However, during the transition period, the forestry administration tried to keep all logging enterprises active. This was done mainly by granting them ventes de coupe or by allowing those which had exploitation licences ${ }^{2}$ before 1994 to continue working

Central Africa: The Central African Republic, Chad, Cameroon, Congo, Gabon, Equatorial Guinea; West Africa: Benin, Togo, Burkina Faso, Côte d'Ivoire, Senegal, Mali, Niger.

2 Exploitation licences were one type of logging rights in the former forestry legislation. They consisted of logging rights to a tract of land covering 10000 - 15000 ha granted to a logging enterprise for five years. Each licence was subdivided into smaller tracts of 2500 ha called assièttes de coupe. The logging enterprise needed to obtain an authorisation to exploit a certain number of assièttes de coupe every year within its licence. 
Map 1. Administrative Map of Cameroon

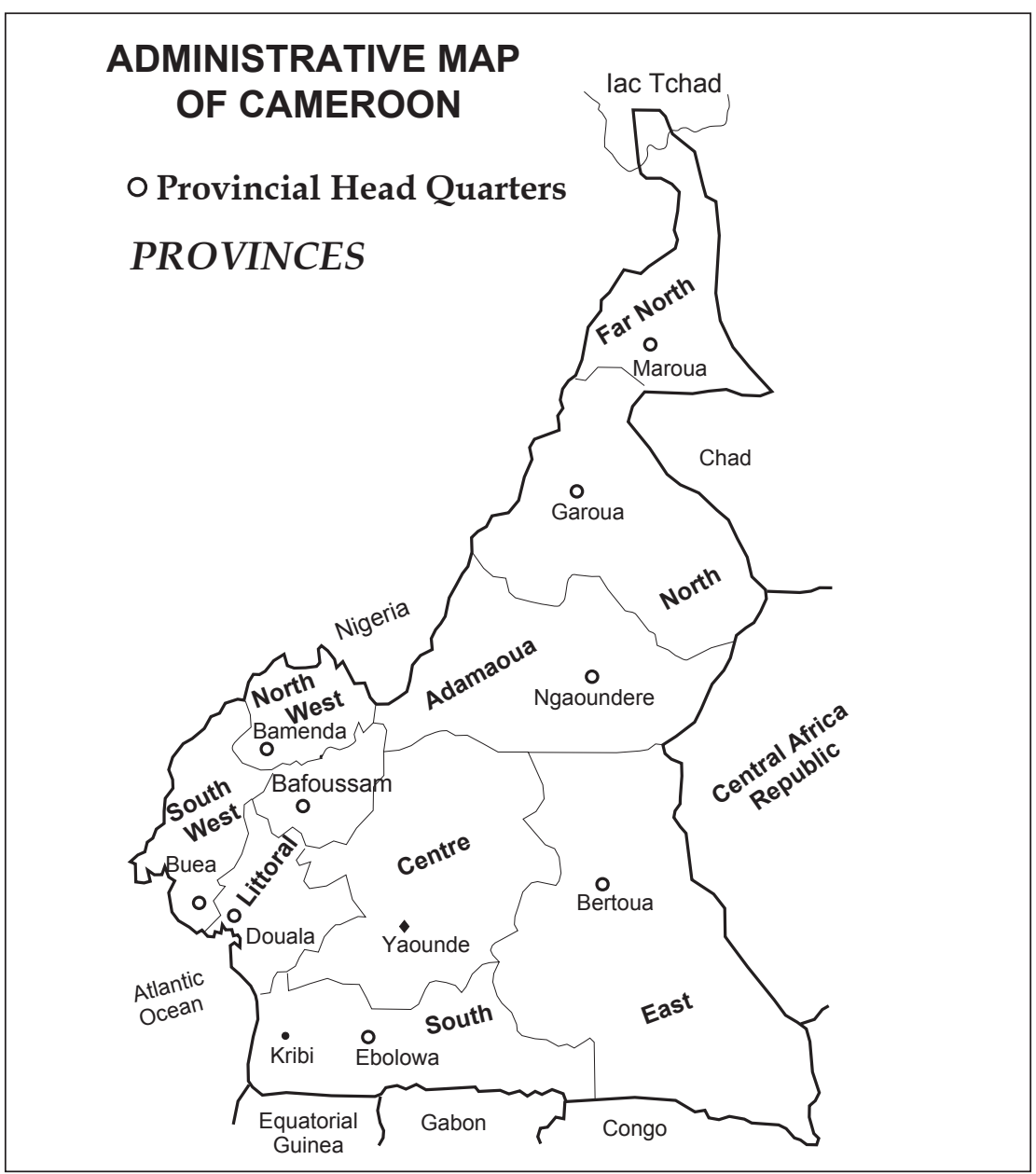

within their licences until expiration. This meant that during the transitional phase, some ventes de coupe were issued to foreigners.

\section{Distribution of Logging Enterprises}

By October 1996, 440 business enterprises had received accreditation from the Ministry in charge of forestry ${ }^{3}$ to become professional logging enterprises since the colonial era (about 1950). Of these, 296 could be identified as having been accredited since 1987 (over the 10 years before the current study), representing $67.2 \%$ of the total number of accredited enterprises. This suggests that logging has attracted more investors since the start of the economic crisis (198687).

By 1996 only 220 logging enterprises were considered to be active, the remainder having gone out of business or still being processed to receive logging rights. The active enterprises were located in six of the ten provinces of Cameroon (Map 1, Table 1). It should be noted that the distribution of logging enterprises is reported according to provinces where the headquarters are located, rather than field operation sites.

Most logging enterprises prefer to have their headquarters where the best communication infrastructure can be found rather than close to their logging site. This is especially true for companies which export logs. In fact, the East province, which has the smallest number of enterprise headquarters, is the one which currently possesses the most important forest resources. (Table 1). More than $57 \%$ of timber products harvested in Cameroon are from the East province, but that province is also the least developed of the six log-producing provinces in terms of communication infrastructure and is the farthest from seaports. Logging activities in natural forests occur only in five provinces. In the West province, logging is concentrated in eucalyptus plantations for the production of poles.

Before the creation of MINEF in 1992, the Ministry of Agriculture was in charge of the forestry sector. 
Table 1. Log production and location of active logging enterprises by province, fiscal year 1995/96

\begin{tabular}{|lccc|}
\hline Province & $\begin{array}{c}\text { Number of logging } \\
\text { enterprises }\end{array}$ & $\begin{array}{c}\text { Enterprises' log } \\
\text { production }\left(\mathbf{m}^{3}\right)\end{array}$ & $\begin{array}{c}\text { Share of national } \\
\text { production (\%) }\end{array}$ \\
\hline Centre & 96 & 447404 & 16 \\
East & 5 & 1600163 & 57 \\
Littoral & 86 & 225388 & 8 \\
South & 15 & 451841 & 3 \\
South West & 12 & 81134 & 0 \\
West & 6 & 0 & 100 \\
Total & 220 & 2805930 & \\
\hline
\end{tabular}

Source: 1996 Forestry Department statistics

Table 2. Distribution of logging enterprises by ownership

\begin{tabular}{|lrrrrrr|}
\hline & Accredited & \multicolumn{2}{c|}{ Active } & \multicolumn{2}{c|}{ Inactive } \\
& Number & $\%$ & Number & $\%$ & Number & $\%$ \\
\hline Domestic & 322 & 73 & 154 & 70 & 168 & 76 \\
Foreign & 96 & 22 & 58 & 26 & 38 & 18 \\
Joint Venture & 22 & 5 & 8 & 4 & 14 & 6 \\
Total & $\mathbf{4 4 0}$ & $\mathbf{1 0 0}$ & $\mathbf{2 2 0}$ & $\mathbf{1 0 0}$ & $\mathbf{2 2 0}$ & $\mathbf{1 0 0}$ \\
\hline
\end{tabular}

Source : Forestry Department (1996)

Table 3. Level of activity of logging enterprises by nationality of ownership

\begin{tabular}{|lrrrrr|}
\hline & \multicolumn{2}{c}{ Domestic } & \multicolumn{2}{c|}{ Foreign } & Total \\
& Number & $\%$ & Number & $\%$ & \\
\hline Active & 154 & 48 & 58 & 60 & 212 \\
Inactive & 168 & 52 & 38 & 40 & 206 \\
Accredited & 322 & 100 & 96 & 100 & 418 \\
\hline
\end{tabular}

Source: Forestry Department (1996)

\section{Structure and Development of the Logging Industry}

\section{Ownership of logging enterprises}

Of the 440 enterprises granted accreditation for logging in Cameroon from the colonial era to 1996, 322 are owned by Cameroon nationals while 96 are foreign enterprises and 22 have mixed capital (Table 2). Of the 220 currently active enterprises, 154 belong to nationals while 58 belong to foreigners and 8 have mixed capital.

Based on the number of enterprises, the Cameroon logging industry is dominated by Cameroon nationals who own at least $70 \%$ of the total number of logging enterprises. However, the proportion of national enterprises in the logging business is higher for accredited than for active businesses, while at the same time the proportion of foreign enterprises increases when comparing accredited to active enterprises. This suggests that fewer national enterprises have had prolonged suc cess in the logging industry.

Fifty-two per cent of accredited enterprises owned by nationals are inactive; the proportion is $40 \%$ for foreign-owned enterprises (Table 3). Reasons for this may include problems related to the access of national enterprises to capital or lack of experience the management of logging activities. However, it should 


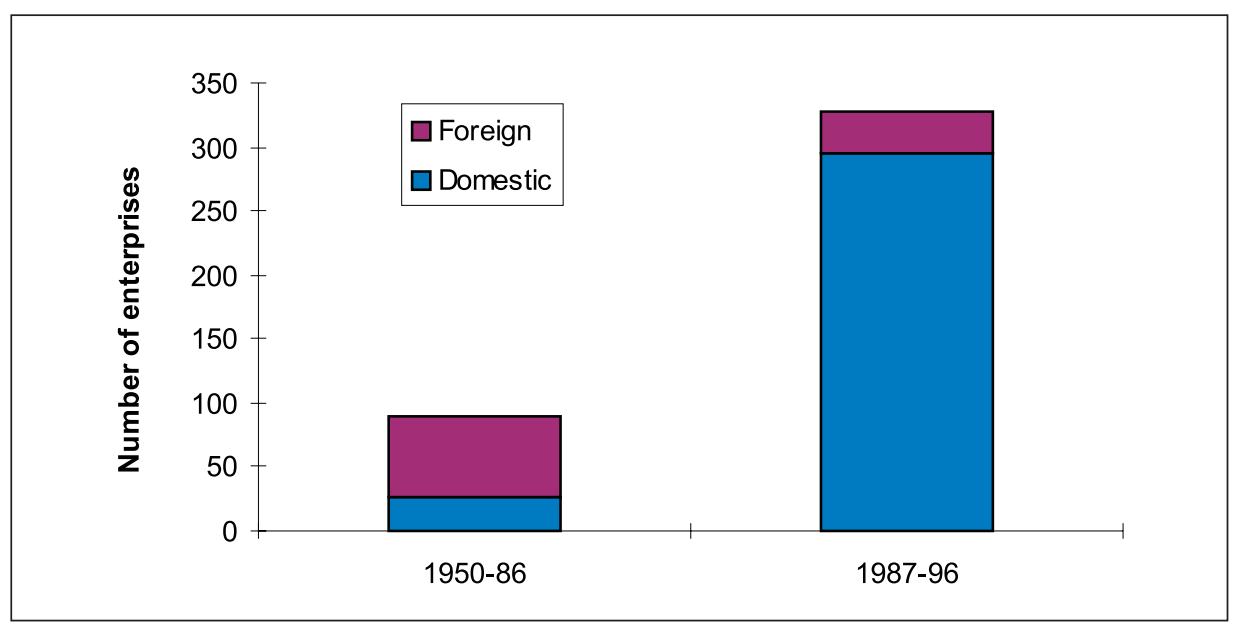

Figure 1. Ownership of accredited logging enterprises, 1950-86 and 1987-96

be emphasised that a large number are just entering the industry. These new enterprises, although accredited, have never been granted logging rights and are thus considered inactive. This is especially true for enterprises owned by nationals. The relatively high level of inactivity for foreign businesses is linked to the length of the period used for reference. In the early period following 1948 nearly all logging enterprises were foreign but many of these have now ceased to operate in Cameroon.

A check between accreditation dates and ownership of logging enterprises reveals that, of the 90 enterprises which were accredited between 1950 and 1986, 26 were owned by nationals while 64 were owned by foreigners. On the other hand, of the 296 accredited between 1987 and 1996, 264 belong to nationals while only 32 are owned by foreign investors (Figure 1).

Before the economic crisis in 1986 and 1987, the logging industry was mainly a business for foreign investors who owned $71 \%$ of the enterprises. However, the industry has attracted mostly Cameroon nationals during the last ten years. Before the downturn, Cameroon nationals invested mainly in agricultural export crops. During the crisis, the prices of these agricultural products decreased sharply which encouraged domestic economic operators to shift to new and more profitable sectors for investment. Logging was identified as one of these new sectors (Figure 2). Logging enterprises prefer to have their head offices in the Centre and Littoral provinces where the communi-

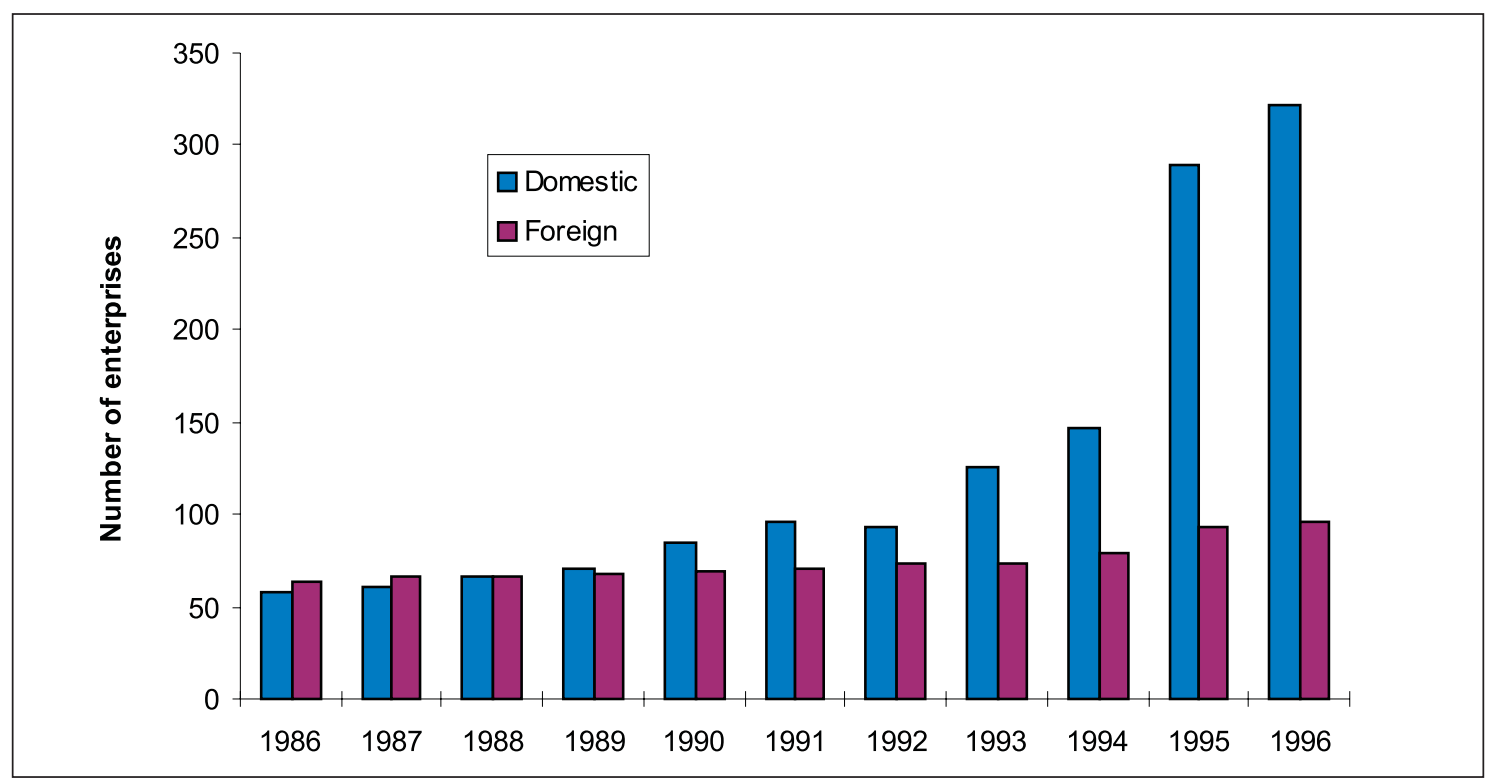

Figure 2. Ownership of accredited logging enterprises over time 
Table 4. Location of active logging enterprises in 1996 by nationality

\begin{tabular}{|lrrrrrrrr|}
\hline \multirow{2}{*}{ Province } & \multicolumn{2}{c}{ Domestic } & \multicolumn{2}{c}{ Foreign } & \multicolumn{2}{c}{ Joint venture } & \multicolumn{2}{c|}{ Total } \\
& Number & $\%$ & Number & $\%$ & Number & $\%$ & Number & $\%$ \\
\hline Centre & 75 & 50 & 17 & 29 & 4 & 50 & 96 & 44 \\
East & 5 & 3 & 0 & 0 & 0 & 0 & 5 & 2 \\
Littoral & 50 & 32 & 34 & 59 & 2 & 25 & 86 & 39 \\
South & 9 & 6 & 6 & 10 & 0 & 0 & 15 & 7 \\
South-west & 10 & 6 & 1 & 2 & 1 & 12.5 & 12 & 5 \\
West & 5 & 3 & 0 & 0 & 1 & 12.5 & 6 & 3 \\
Total & 154 & 100 & 58 & 100 & 8 & 100 & 220 & 100 \\
\hline
\end{tabular}

Source: Forestry Department (1996)

cation infrastructure is adequate and where the decision making centres are located (Table 4). Yaoundé in the Centre province is the political capital of Cameroon while Douala in the Littoral province is the main seaport of the country. However, while Cameroon nationals prefer the Centre $(50 \%$ of their enterprises are located there compared to $32 \%$ in the Littoral), foreigners prefer the littoral $(59 \%)$ to the Centre $(29 \%)$. Taking into account the fact that the biggest seaport facility is located in the Littoral (at least $90 \%$ of overseas traffic goes through Douala), it appears that foreign enterprises are more oriented toward timber exports than Cameroon nationals. This is further shown by the fact that, except for the Centre province, foreign enterprises are based in the Littoral, South, and South-west provinces where seaports exist.

\section{Industrial log production}

Statistics collected from the Forestry Department and the regional offices of MINEF indicate that, during the fiscal year 1995/96, log production amounted to 2805 $930 \mathrm{~m}^{3}$. This production was distributed among different types of logging activities (Table 5). Conventional logging, which is conducted by accredited loggers, accounted for more than $98 \%$ of total log production.

With regard to the share of conventional logging, only 113 enterprises were actually involved in timber harvesting (out of 220 considered by MINEF to be 'active') (Table 6). The remainder have been accredited and are in the process of applying for logging rights, or they have exhausted their previous rights and have applied within the new legal context which is not yet fully operational. Some enterprises which are not directly involved in practical logging continue to be active in log processing and trade. Among the 113 enterprises practising logging in the field, 78 are owned by Cameroon nationals, 28 by foreign investors and seven are joint ventures (mixed capital) (Table 4). Although a small number, enterprises of foreigners are responsible for most of the $\log$ production in Cameroon. On average, an enterprise owned by foreign investors harvests about five times more timber than one owned by Cameroon nationals. However, these proportions may change in the future because the industry is in a transitional phase and the interest of Cameroon nationals in logging is still new.

Table 5. Timber harvest volumes by type of logging

\begin{tabular}{|lc|}
\hline Type of logging & Volume harvested $\left.\mathbf{( m}^{\mathbf{3}}\right)$ \\
\hline Conventional logging & 2752845 \\
Recuperation $^{\mathrm{a}}$ & 39990 \\
Illegal harvesting $^{\text {Total }}$ & 12097 \\
\hline
\end{tabular}

Source: MINEF

Note: a Timber harvesting conducted in agricultural land as part of land clearing prior to copping. Authorisations for these types of timber harvesting are given to farmers who usually subcontract the field activities and sell the logs to professional loggers. 
Table 6. Log harvest by nationality of logging entrepreneurs

\begin{tabular}{|lccr|}
\hline $\begin{array}{l}\text { Nationality of } \\
\text { entrepreneurs }\end{array}$ & $\begin{array}{c}\text { Number of } \\
\text { enterprises }\end{array}$ & $\begin{array}{c}\left.\text { Total log production } \mathbf{( m}^{\mathbf{3}}\right) \\
\left.\text { production } \mathbf{( m}^{\mathbf{3}}\right)\end{array}$ & $\begin{array}{c}\text { Average production } \\
\left.\mathbf{( \mathbf { m } ^ { 3 }}\right)\end{array}$ \\
\hline Domestic & 78 & 997952 & 12794.26 \\
Foreign & 28 & 1724091 & 61574.68 \\
Joint venture & 7 & 30802 & 4400.29 \\
Total & $\mathbf{1 1 3}$ & $\mathbf{2} \mathbf{8 0 4} \mathbf{9 3 2}$ & \\
\hline
\end{tabular}

Source: MINEF (1996)

\section{Primary processing capacity}

In Cameroon, only primary processing firms, including sawmills, veneer and plywood factories, are considered part of the forestry sector. In total, there are 60 primary wood processing units in Cameroon (Annex 5). These units include 49 sawmills, 7 veneer factories and 4 plywood factories. Among the 7 veneer factories, one produces sliced veneer while the rest produce rotarycut veneer. There are 4 complexes each integrating a sawmill, a rotary cut veneer factory and a plywood factory, in addition to one which is integrated with a match factory. Of the 60 processing units, 34 belong to foreign investors, 21 to Cameroon nationals and 5 are joint ventures (Table 7).

The total installed capacity of these 60 processing units amounts to $1988100 \mathrm{~m}$ of roundwood. They range from a small sawmill capable of processing $5000 \mathrm{~m}$ of raw logs per year to a complex firm comprising a sawmill, a rotary-cut veneer factory and plywood factory with a processing capacity of $168000 \mathrm{~m}^{3}$ of $\operatorname{logs}$ per year.
By comparing the total log production of Cameroon (2 $805930 \mathrm{~m}^{3} /$ year) with the volume of raw logs exported (1 $254407 \mathrm{~m}^{3} /$ year), it can be assumed that about 1 $550525 \mathrm{~m}^{3}$ of logs are processed in Cameroon. This is $22 \%$ lower than the installed capacity. The Cameroon's forestry regulation and forest policy statement (MINEF 1995) define a target for processing at least $70 \%$ of the total $\log$ production within Cameroon, but the above value represents only $55.3 \%$. Thus, the actual volume processed is both below the nominal capacity of established firms and the forest policy targets. Reasons for this may be that some of the existing factories are obsolete and the forestry administration has not put in place adequate incentives to encourage processing.

Foreigners own larger timber processing units compared to those of Cameroon nationals (Table 8). In contrast to the distribution of head offices (Table 1), processing units are located closer to resources (Table 9). The East province which produces the largest volume of logs, has the biggest timber processing capacity and the largest number of processing units.

Table 7. Primary wood processing units by ownership regime

\begin{tabular}{|llr|}
\hline Ownership & Type of processing unit & Number \\
\hline Domestic & sawmills & 20 \\
& rotary-cut veneer & 1 \\
Foreign & sawmills & 26 \\
& rotary cut & 4 \\
& plywood & 4 \\
Joint venture & sawmills & 3 \\
& rotary-cut veneer & 1 \\
& sliced veneer & 1 \\
Total & & $\mathbf{6 0}$ \\
\hline
\end{tabular}


Table 8. Capacity of timber processing units by nationality

\begin{tabular}{|lccc|}
\hline Ownership & $\begin{array}{c}\text { Largest unit } \\
(\mathbf{m} 3)\end{array}$ & $\begin{array}{c}\text { Smallest unit } \\
(\mathbf{m} 3)\end{array}$ & Average capacity \\
\hline Domestic & 50000 & 5000 & 20081 \\
Foreign & 168000 & 10000 & 50926 \\
Joint venture & 72000 & 14400 & 38280 \\
\hline
\end{tabular}

Table 9. Distribution of timber processing units and installed capacity among provinces

\begin{tabular}{|lcccc|}
\hline Province & \multicolumn{2}{c}{ Processing mills } & \multicolumn{2}{c|}{ Installed capacity } \\
& Number & $\%$ & Processing capacity $\left(\mathrm{m}^{3}\right)$ & $\%$ \\
\hline East & 21 & 36 & 812000 & 42 \\
Centre & 15 & 25 & 506000 & 25 \\
Littoral & 14 & 23 & 367700 & 18 \\
South & 8 & 13 & 233400 & 12 \\
West & 2 & 3 & 69000 & 3 \\
Total & $\mathbf{6 0}$ & $\mathbf{1 0 0}$ & $\mathbf{1 9 8 8} \mathbf{1 0 0}$ & $\mathbf{1 0 0}$ \\
\hline
\end{tabular}

Table 10. Wood product exports from Cameroon seaports, fiscal year 1995/96

\begin{tabular}{|lrc|}
\hline Seaport & Raw log exports $\left.\mathbf{( m}^{\mathbf{3}}\right)$ & Lumber $\left(\mathbf{m}^{\mathbf{3}}\right)$ \\
\hline Douala & 1155791 & 207959 \\
Campo & 53081 & 13736 \\
Kribi & 24693 & 14645 \\
Limbe & 20842 & 0 \\
Total & $\mathbf{1 2 5 4} \mathbf{4 0 7}$ & $\mathbf{2 3 6} \mathbf{3 4 0}$ \\
\hline
\end{tabular}

\section{The market for Cameroon timber products}

\section{The export market}

Timber products, both logs and processed products, are exported from four seaports: Douala in the Littoral province; Kribi and Campo in the South province; and Limbe in the South-west province (Table 10).

The current level of timber product exports from Cameroon is about $1254407 \mathrm{~m}^{3}$ of logs, $236340 \mathrm{~m}^{3}$ of lumber and $35000 \mathrm{~m}^{3}$ of veneer and plywood per year. Using an average recovery rate of $35 \%$ in Cameroon sawmills (Dongmo 1996), the roundwood equivalent estimate for lumber exports is $675255.2 \mathrm{~m}^{3}$ per year; $35000 \mathrm{~m}^{3}$ of plywood and veneer with an average recovery rate estimated at 57\% (Ngono et al. 1994) gives $54950 \mathrm{~m}^{3}$ roundwood equivalent. Thus, the total export of timber products from Cameroon in roundwood equivalent can be estimated at $984612 \mathrm{~m}^{3}$, representing about $70.7 \%$ of the total $\log$ production of Cameroon.

Douala is the main seaport from which most timber products are exported (more than $92 \%$ of raw logs and $88 \%$ of lumber) (Table 10 ). This explains why many enterprises involved in timber products exports prefer to have their head offices in Douala or close to it (Littoral province). In fact, in each of the three other seaports there is one big company conducting most of the activities.

In our sample of 82 active enterprises, 42 were involved in wood product exports. From these statistics, it may be deduced that about half of the logging enterprises operating in Cameroon are exporting wood products. About two-thirds of actual log exports from 
Table 11. Wood product exporting enterprises

\begin{tabular}{|lccc|}
\hline Ownership & $\begin{array}{c}\text { Number of } \\
\text { enterprises }\end{array}$ & $\begin{array}{c}\text { Average log volume } \\
\text { exported }\left(\mathbf{m}^{\mathbf{3}}\right)\end{array}$ & Total log exports \\
\hline Domestic & 20 & 8543 & 170863 \\
Foreign & 18 & 2610 & 388985 \\
Joint venture & 4 & 8671 & 34691 \\
\hline
\end{tabular}

Figure 3. Log exports by ownership of enterprises

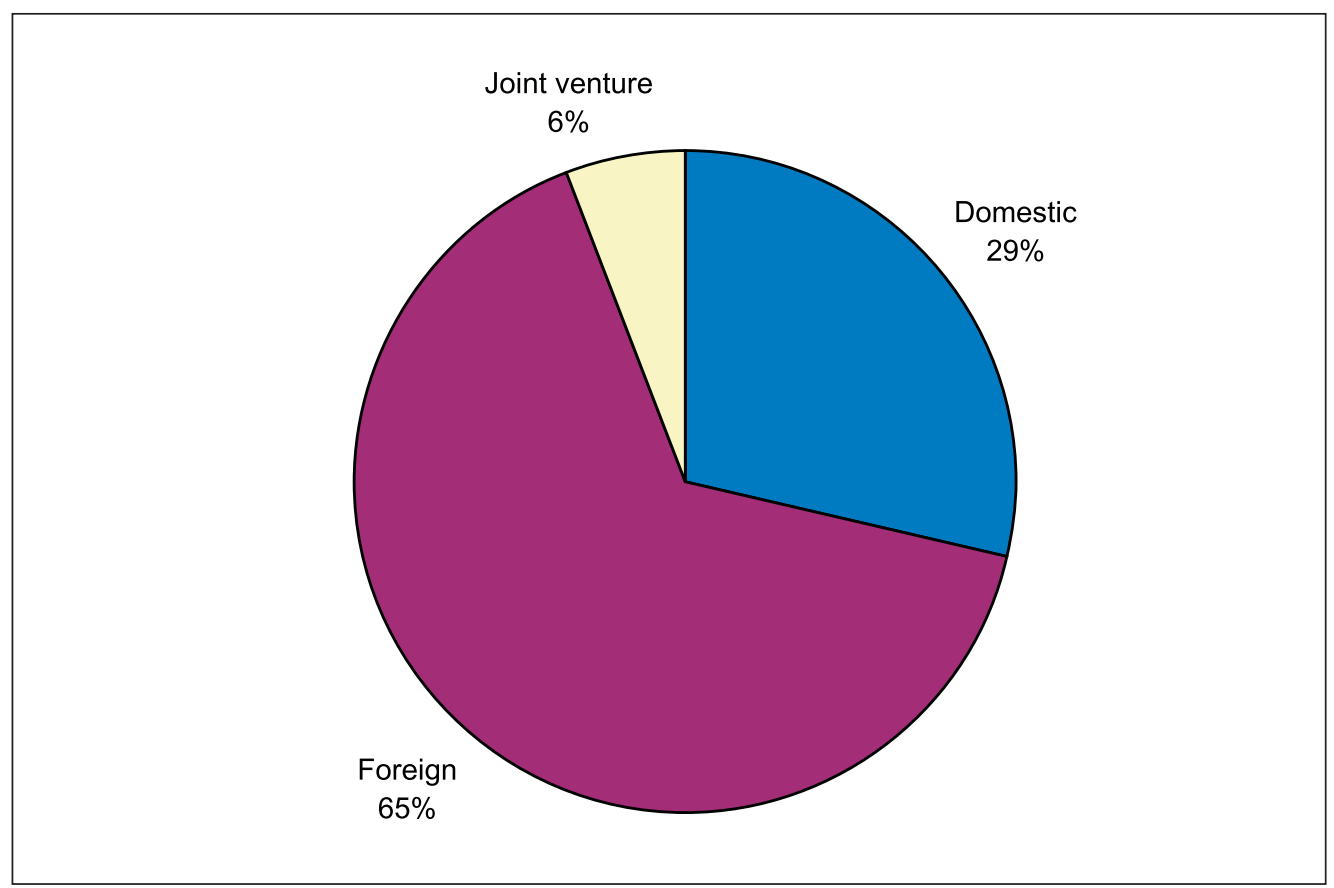

Cameroon are controlled by enterprises of foreign investors (Table 11, Figure 3). Of the sample of wood product exporting enterprises, six (about $7.3 \%$ of all enterprises) export more than $50 \%$ of the total volume of logs going out of Cameroon, and all these companies are European-owned. Keeping in mind the importance of exports in the Cameroon logging industry, it means that the logging industry in Cameroon is dominated by a small number of foreign companies that may be able to influence pricing and policy.

The domestic market

The national domestic market accounts for about
$821320 \mathrm{~m}^{3}$ of roundwood equivalent, representing $29.3 \%$ of the total $\log$ production of Cameroon. All the domestic consumption is as processed products, mainly lumber, plywood and matches. These products are mostly of lower quality and cannot be exported. An important share of the national market is out of the control of the forestry administration and is supplied by local and illegal sawnwood. However, it should be noted that, part of what is considered to be local consumption is exported illegally to neighbouring countries (mainly Nigeria and Chad). No effort has been made in this study to estimate the quantity of this illegal trade. 


\section{IMPORTANCE OF THE LOGGING INDUSTRY IN THE CAMEROON NATIONAL ECONOMY}

\section{Contribution to the Balance of Payments}

During the fiscal year 1995/96, which was the last year for which a complete data set on external trade of Cameroon was available (MINDIC 1996), the total value of exports from Cameroon was 811.02 billion CFA Francs (FCFA) which is approximately equivalent to 1.65 billion US dollars (USD). The contribution of timber product exports to total exports amounts to 160.53 billion FCFA (321.1 million USD), representing $19.8 \%$ of the total value of exports from Cameroon (Table 12).

\section{Contribution to National Employment}

In the 82 sample enterprises, the total number of employees was 13 701, subdivided by professional qualification (Table 13).

Compared to enterprises owned by foreign investors and joint ventures, logging enterprises of Cameroon nationals tend to be smaller firms with fewer qualified employees (Table 14). Based on the average number of employees at each qualification level, in combination with the total number of active logging enterprises by nationality of owners (Table 2), the total employment of the logging industry in Cameroon can be estimated to be 34301 people. From the data it is apparent that the logging industry is dominated by the least qualified personnel. Labourers account for $92 \%$ of the total number of employees (Figure 4).

All labourers in the sample were Cameroon nationals. Nine supervisors out of 651 were foreigners (Europeans), which represents about 1.4\%, and 228 executives out of 595 (about 38.32\%) were foreigners (Europeans and Asians). Except for one person, all foreign executives were employed by enterprises owned by foreigners. In fact, more than half of the executive staff (about 55\%) employed by big foreign enterprises are foreigners. Almost all foreigners employed in the Cameroon logging industry hold executive positions in big enterprises owned by foreign investors.

\section{Contribution to Gross National Product and Government Revenues}

The latest estimate of the contribution of timber harvesting to GNP is $6.7 \%$ (Table 15). This contribution has grown consistently over the last few years both in absolute and relative terms. The percentage contribution has increased from $3.5 \%$ during fiscal year $1989 / 90$ to $6.7 \%$ in $1995 / 96$. It should be noted that these statistics include only timber harvesting and not primary processing which falls under the responsibility of MINEF. The Department of Statistics and National Accounting considers primary processing to fall within the secondary sector, so the full contribution of the logging industry to the national economy is underestimated by these data.

As a contribution to government revenues, the logging industry provides income through felling taxes (based on market values of different timber species), areabased taxes, miscellaneous (including penalties and special permits) and export taxes. The first three types of taxes are collected by the Forestry Department while the last one is collected by the Customs Department. Taxes collected by the Cameroon government from the logging industry grew from 9.05 billion FCFA in 1992/93 to 15.99 billion FCFA in 1993/94 and 28.7 billion FCFA in 1994/95 (derived from data of the Forestry Department and the Department of Statistics and National Accounting in Cameroon). For the most recent fiscal year (1995/95) the contribution was 28.95 billion FCFA in a total government budget of 660.2 billion FCFA. This then represents a relative contribution of $4.4 \%$ to government revenues. Total log production during the same year was about 2.8 million $\mathrm{m}^{3}$, which suggests an average of 10339 FCFA (approximately 20 USD) of taxes per cubic metre. This contribution appears low compared to the contributions to the balance of payments and GNP, suggesting that returns from the logging industry contribute mainly to the development of the private sector.

Table 12. Contribution of timber products to the export revenues of Cameroon

\begin{tabular}{|lcr|}
\hline Product type & \multicolumn{2}{c|}{ Contribution to export revenues } \\
& Value (million FCFA) & $\%$ \\
\hline Logs & 89308 & 55 \\
Lumber & 60369 & 38 \\
Veneer and plywood & 10850 & 7 \\
Total & $\mathbf{1 6 0 5 2 7}$ & $\mathbf{1 0 0}$ \\
\hline
\end{tabular}


Figure 4. Categories of employees in the Cameroon logging industry

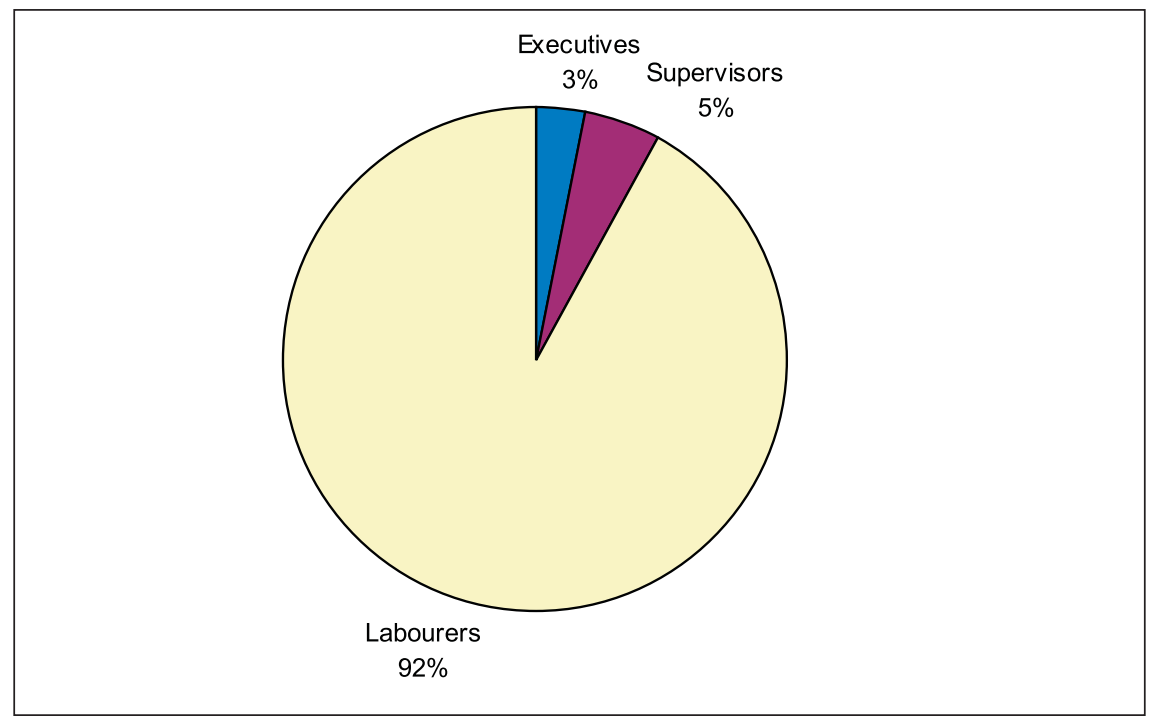

Table 13. Qualification level of employees in 82 logging enterprises

\begin{tabular}{|lr|}
\hline Qualification & Number of employees \\
\hline Executives & 595 \\
Supervisors & 651 \\
Labourers & 12455 \\
Total & $\mathbf{1 3 7 0 1}$ \\
\hline
\end{tabular}

Table 14. Average number of employees per logging enterprise by ownership category

\begin{tabular}{|lccccr|}
\hline $\begin{array}{l}\text { Enterprise } \\
\text { ownership }\end{array}$ & $\begin{array}{c}\text { Sample } \\
\text { size }\end{array}$ & Executives & Supervisors & Labourers & Total \\
\hline Foreign & 23 & 11.3 & 16.3 & 301.2 & 328.8 \\
Domestic & 53 & 2.6 & 4.0 & 68.8 & 75.4 \\
Joint venture & 6 & 7.3 & 7.0 & 314.5 & 328.8 \\
\hline
\end{tabular}

Table 15. Contribution of timber harvesting to GNP of Cameroon (in billion FCFA)

\begin{tabular}{|lcccccc|}
\hline & $\mathbf{1 9 9 0 / 9 1}$ & $\mathbf{1 9 9 1 / 9 2}$ & $\mathbf{1 9 9 2 / 9 3}$ & $\mathbf{1 9 9 3 / 9 4}$ & $\mathbf{1 9 9 4 / 9 5}$ & $\mathbf{1 9 9 5 / 9 6}$ \\
\hline $\begin{array}{l}\text { Timber harvesting } \\
\text { silviculture (billion FCFA) }\end{array}$ & 122 & 128 & 134 & 206 & 276 & 306 \\
$\begin{array}{l}\text { Total GNP (billion FCFA) } \\
\text { Contribution of timber } \\
\text { harvesting to total GNP }\end{array}$ & 3513 & 3340 & 3125 & 3425 & 4427 & 4570 \\
\hline
\end{tabular}

Source: Archives of Department of Statistics and National Accounting, Ministry of Economy and Finance, Cameroon 


\section{THE CAMEROON LOGGING INDUSTRY AND THE DEVALUATION OF THE CFA FRANC}

\section{The CFA Franc}

The CFA franc was created in 1948 as a common currency for French colonies in Africa (Crespi 1994). Initially the acronym CFA stood for 'Communauté française d'Afrique', meaning 'French Community of Africa'. After the French colonies of Africa became independent around 1960, the meaning for the same acronym was changed to 'Communauté financiaire d'Afrique' or 'Financial Community of Africa'. The currency is now shared by 13 African countries, including 12 former French colonies and one former Spanish colony (Equatorial Guinea). These countries are grouped into two central banks, one for the six countries of Central Africa (BEAC) and the other for the countries of West Africa (BCEAO).

The functioning of the CFA zone is based on four main principles (Allechi and Niamkey 1994) of:

- a fixed parity between the French franc (FF) and the CFA franc;

- full convertibility of the FCFA into FF, guaranteed through the special operations account opened at the French treasury;

- free transferability without limit within member countries and between these countries and France; and

- a pooled reserves system under which the Franc zone uses a common exchange rate policy against all other currencies.

Until January 1994, the fixed exchange rate was defined as 50 FCFA francs for one FF (approximately one USD for 280.28 FCFA) (Crespi 1994).

\section{Economic Crisis in Cameroon}

From its independence in 1960 to 1985, Cameroon's economy experienced quite positive development. Export products were diversified even though they were mainly agricultural raw materials. In 1978, the country started to export crude oil which significantly boosted its economic growth (Alibert 1992). The country's GDP grew at $4.8 \%$ annually in real terms between 1960 and 1978, and at a record rate of $8.2 \%$ per year between 1978 and 1986. Until 1978, the contribution of agriculture to GDP and exports were $30 \%$ and $74 \%$ respectively. However, between 1978 and 1986 agriculture's share declined to $22 \%$ of GDP and $51 \%$ of exports (Ntangsi 1991).

During the fiscal year 1986/87 Cameroon recorded a drop of $27.8 \%$ in its exports revenues (Alibert 1992). This resulted from the simultaneous fall in prices of oil products and agricultural products, precipitating the economic and financial crisis. GDP declined by more than $15 \%$ between 1987 and 1990 and, for the first time in Cameroon's history, government operations recorded a large deficit of 508 billion FCFA (at 1987 prices), equivalent to $12 \%$ of GDP. Public investment decreased by $40 \%$ during the fiscal year $1987 / 88$, and then by $45 \%$ in $1988 / 89$ (Alibert 1992).

\section{Structural Adjustment in Cameroon}

The economic crisis in Cameroon had both external causes, mainly the drop in prices of export products, and also internal and structural causes. The internal structural problems include an blow-out of public expenditures and a crisis of public finance, a high-cost domestic economy, and a stagnant and non-competitive industry in both international and domestic markets. Some analysts have also emphasised the poor management and misuse of national resources by a careless bureaucratic public administration (Vallée 1988; Jua 1991).

At first, the Cameroon government tried to address the problem of the economic crisis independently, but without success. It finally signed a stand-by agreement with the International Monetary Fund (IMF) in September 1988 and a structural adjustment loan in June 1989, years after most countries of sub-Saharan Africa had undertaken similar agreements.

In Cameroon, as in other African countries South of the Sahara, the international financial institutions (the World Bank and the IMF) based the Structural Adjustment Programme on three general guiding principles (World Bank 1994).

- Keep budget deficits low and the exchange rate right: this would be achieved by strong fiscal discipline, devaluation whenever necessary and privatisation.

\footnotetext{
4 Central Africa: The Central African Republic, Chad, Cameroon, Congo, Gabon, Equatorial Guinea; West Africa: Benin, Togo, Burkina Faso Cote d'Ivore, Senegal, Mali, Niger.

BEAC: Banque des états de l'Afrique Centrale; BCEAO: Banque Centrale des ètats de l'Afrique de l'Ouest
} 
- Foster competition at home and abroad through appropriate export-led strategies, domestic deregulation, trade reform and divestiture of public enterprises.

- Use scarce government resources wisely by avoiding state intervention where markets can work even moderately well.

Because of Cameroon's membership in the CFA zone, measures dealing with external adjustment such as currency devaluation could not be considered initially. For the devaluation of the CFA franc to occur, there had to be an agreement among all member countries of the CFA zone. Thus, at first, the Structural Adjustment for Cameroon concentrated on internal factors and was made up of four interrelated components (Ntangsi 1991).

- Macro-economic stabilisation with the aim of restoring the equilibrium of the budget and current account as well as lowering the level of the country's external indebtedness to a bearable level.

- $\quad$ Price, trade and market reform to liberalise prices and wages, and replace quantitative restrictions with tariff protection, to encourage competition and efficiency which would result in lower production costs, and therefore in greater competitiveness in the international market.

- Public sector enterprise and banking reform to retain in the state portfolio only public enterprises that were strategic and to disengage from those that were not, either through privatisation or liquidation.

- Institutional reform and role of the state covering the reform of institutional, legal and regulatory frameworks which also require the rationalisation of the role of the state. There must be a reduced role for the public sector and greater reliance on the private sector.

\section{Devaluation}

In early 1993, it became obvious that efforts by most CFA zone member countries were not yielding the expected results. The average growth of GDP in real terms was estimated for the year 1993 to be $-1.4 \%$ and $-2.0 \%$ respectively for West African and Central African regions of the CFA zone (Goreux 1996). The average growth rate of GDP for the whole zone was estimated at $-1.7 \%$, and the rate for Cameroon was 4\%. Many analysts blamed an artificially high exchange rate which prevented member countries of the CFA zone from becoming more competitive in international markets. This also aggravated the deficit in the balance of payments. Tchoungui et al. (1995) who concentrated on the case of Cameroon, identified two main reasons for the failure of the first SAP. First the exchange rate question was ignore for too long, which deprived the adopted policies of an essential instrument of control for which other budgetary measures were unable to compensate. Secondly, governance was inadequate, whether through lack of political consensus, full realisation by the economic authorities of the importance of the economic measures to be taken, or absence of the necessary coordination of the admittedly complex steps of the SAP.

The Heads of States of the CFA zone member countries took the decision to devaluate the CFA franc in January 1994 and the new fixed rate with the FF became 100 FCFA to one FF.

\section{The Effects of Devaluation on the Cameroon Logging Industry}

\section{General aspects of structural adjustment and forest resource management}

For the last two decades, many developing countries have implemented structural adjustment policies, and the effects of these policies on natural resources have been rather controversial. Kessler et al. (1996) identified a number of ways in which forest resources are negatively affected by SAPs. These include an increase in commercial extraction rates and forest clearing for subsistence needs, enhanced commercial viability of many forestry sectors by SAP-brokered changes in exchange rate policies and market liberalisation, and declining forest resource management because of budget cuts.

SAPs have been criticised as contributing to forest resource degradation in a number of ways (Kaimowitz et al. 1997). Migration to agricultural areas may occur as a result of increased unemployment and rural poverty. Forest clearing for agricultural product exports can be stimulated through currency devaluation, fiscal incentives for exports and the removal of agricultural price controls. Also timber exports are promoted through currency devaluation. SAPs also reduce the public sector's capacity to control illegal deforestation and regulate the timber industry because of required budget cuts.

Supporters of SAPs have emphasised positive economic results structural adjustment policies have yielded in many developing countries without necessarily being linked to negative environmental impacts (Monasinghe and Cruz 1994; World Bank 1994). Kessler et al. (1996) also noted positive effects on for- 
est regeneration and increased use of industrial forestry practices which tend to reduce pressure on natural forests. In general, the World Bank believes that 'although most adjustment programs have not focused on environmental issues, most of them include measures that, on balance, appear likely to help rather than to hurt the environment' (World Bank 1990).

\section{Structure of the logging industry of Cameroon}

Devaluation has had an impact on the logging industry of Cameroon in the evolution of timber harvesting capacity, which is illustrated by the number of enterprises, and the development of timber processing capacity.

\section{Number of logging enterprises}

Although the total number of logging enterprises has continuously increased from 1986-1996, the increase was particularly spectacular after the devaluation in 1994 (Figure 5). From 1994 to 1995, the total number of enterprises in the logging industry grew from 194 to 351 , an increase of about $81 \%$. These figures suggest that devaluation has attracted the business community of Cameroon to logging, certainly because the profit margin of the logging industry has improved as well as the competitiveness of Cameroon timber products in international markets. Most of the new interest has come from Cameroon nationals. However it should be noted that, after the devaluation, nationalities of foreign investors have diversified with new investors coming from Southeast Asia. In particular, companies from Thailand and Malaysia have established two important enterprises.
Timber processing capacity

In sharp contrast to the change in the number of logging enterprises, timber processing capacity in Cameroon has not increased substantially since devaluation. Only five new sawmills and one rotary-cut veneer factory have been installed since the devaluation, mainly by foreign investors. This may be due to the fact that Cameroon nationals, who have shown renewed interest in logging since devaluation, do not have enough resources to invest in timber processing.

\section{Effects on forest resources}

\section{Timber harvesting}

Based on Forestry Department statistics from 1986/87 to $1995 / 96$, annual volume of logs harvested from Cameroon forests grew suddenly after devaluation (Figure 6). During the fiscal year 1993/1994, the volume of $\operatorname{logs}$ harvested in Cameron forests had decreased for three successive years. Immediately after devaluation, timber harvests increased considerably over 2.5 million $\mathrm{m}^{3}$ for the first time in Cameroon logging. Compared to the preceding fiscal year, 1993/94 saw an increase of more than $34 \%$ in volume of timber harvested, with even higher volumes being harvested during the remaining two years for which data are available. It seems clear that the devaluation of the CFA francs has resulted in a boost in log production in terms of volume harvested. The origin of the additional volume will be investigated in the coming sections.

\section{Log exports}

More than $90 \%$ of all exported logs are shipped from the Douala seaport (Figure 7). Just after devaluation,

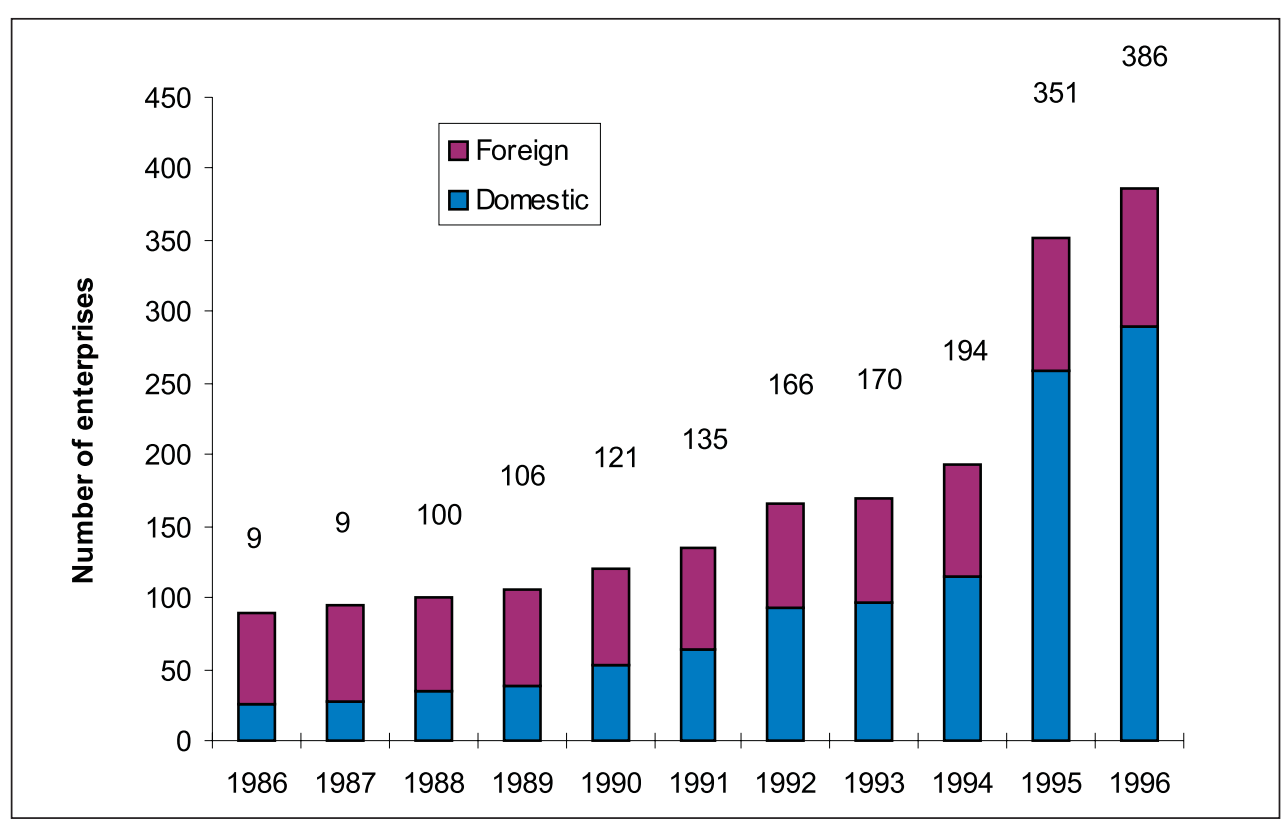

Figure 5. Accredited logging enterprises, 1986-1996 


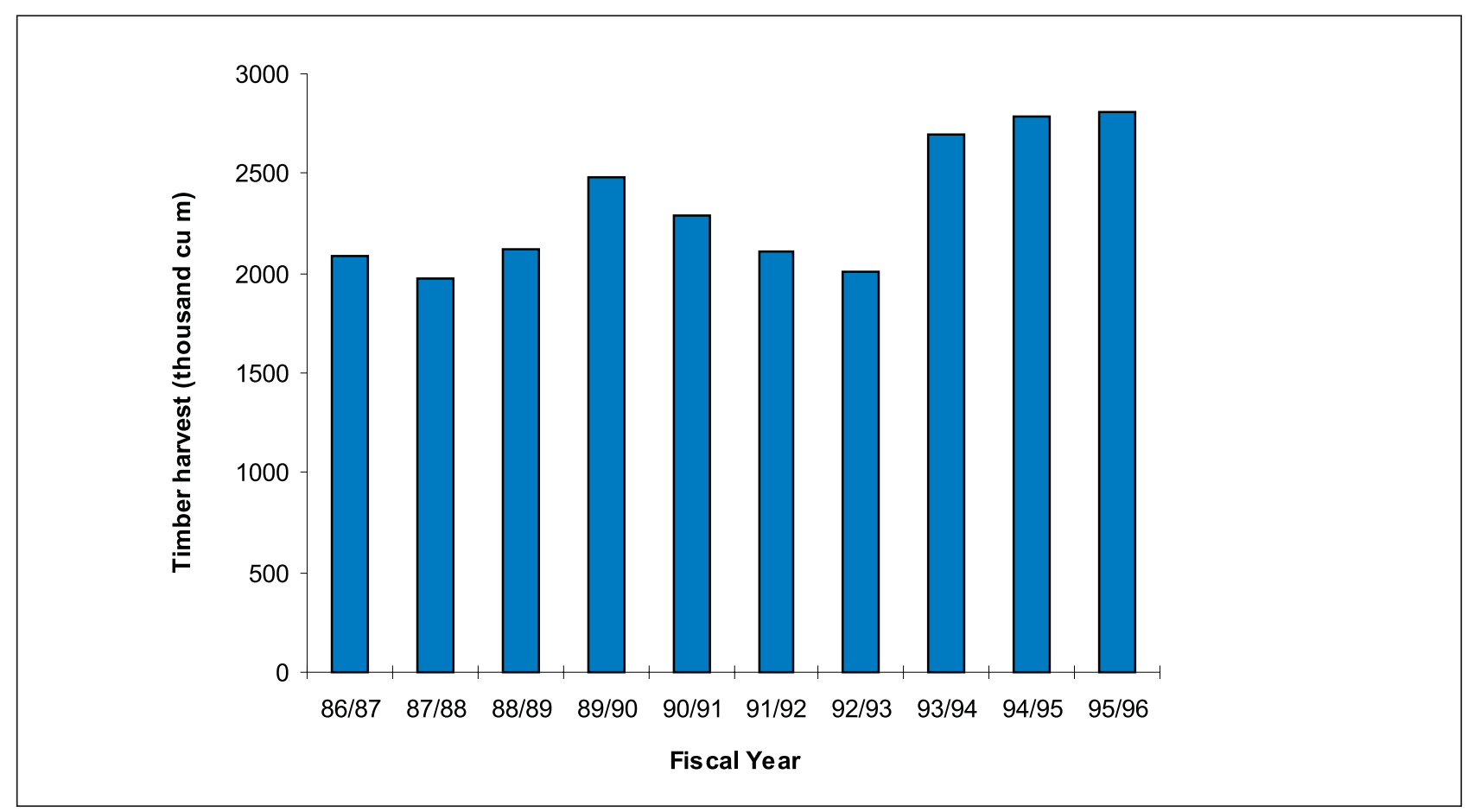

Figure 6. Timber volume harvested in Cameroon forests, 1986/87-1995/96

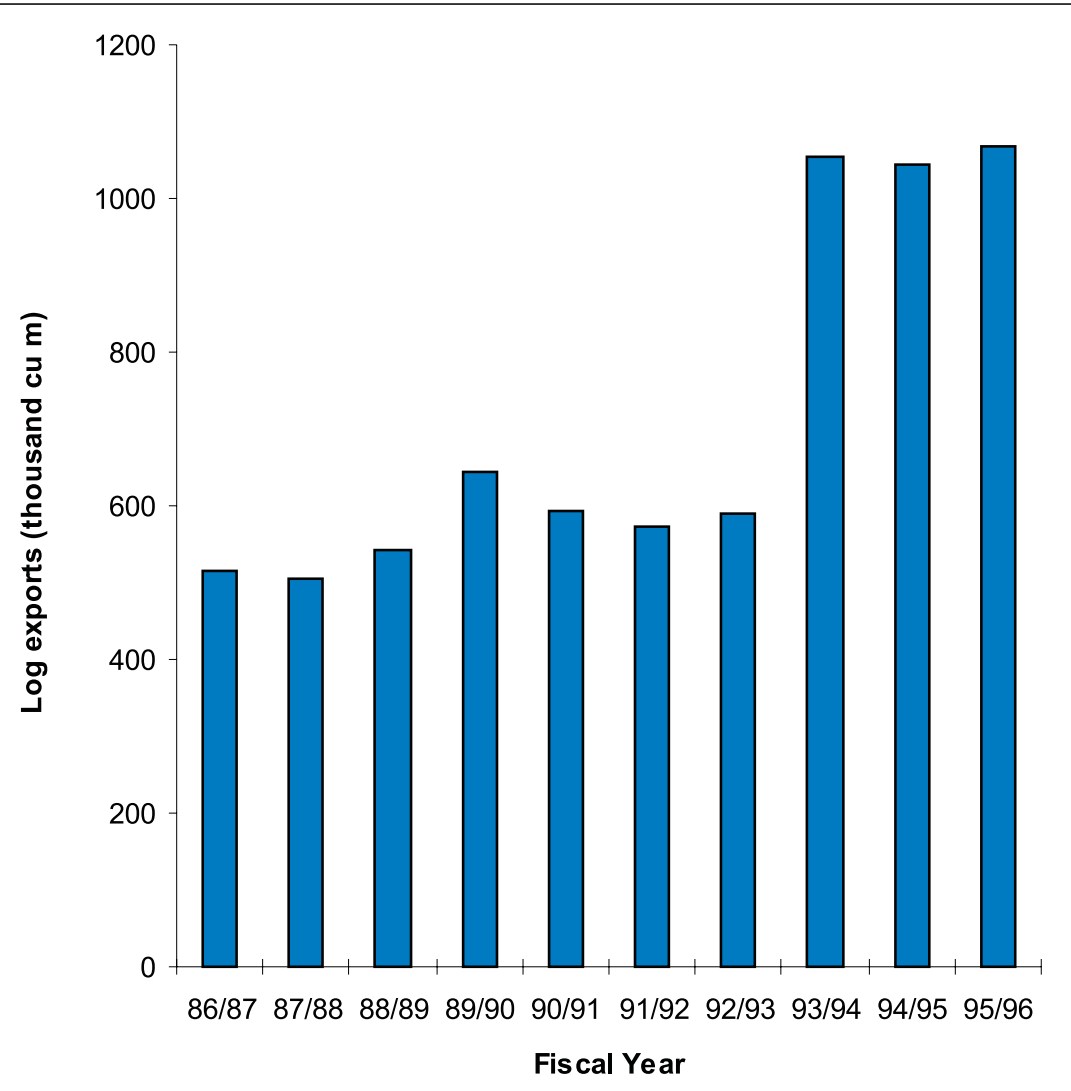

Figure 7. Log exports from the seaport of Douala, 1986/87-1995/96 
Table 16. Ventes de coupe (2500 ha of forest area each) granted by the forestry administration to loggers between July 1991 to June 1996

\begin{tabular}{|lccc|}
\hline & Domestic & Foreign & Total \\
\hline $1991 / 92$ & 48 & 17 & $\mathbf{6 5}$ \\
$1992 / 93$ & 100 & 33 & $\mathbf{1 3 3}$ \\
$1993 / 94$ & 127 & 44 & $\mathbf{1 7 1}$ \\
$1994 / 95$ & 115 & 53 & $\mathbf{1 6 8}$ \\
$1995 / 96$ & 127 & 46 & $\mathbf{1 7 3}$ \\
Total & $\mathbf{5 1 7}$ & $\mathbf{1 9 3}$ & $\mathbf{7 1 0}$ \\
\hline
\end{tabular}

Note: These data only include ventes de coupe

the volume of logs exported increased by almost $80 \%$. Before devaluation between $500000 \mathrm{~m}$ and 6005000 $\mathrm{m}^{3}$ of logs were shipped from this port each year, whereas after devaluation this figure grew to over one million $\mathrm{m}^{3}$ per year. This level of exports continued for the next two years. It is clear that the devaluation of the CFA franc has resulted in a substantial increase in log exports from Cameroon. Although the available data for the export of processed products were not complete, they suggest the same trend for lumber and other processed products.

\section{Areas opened for logging}

While both the number of logging enterprises and the volume of annual log production have increased substantially in Cameroon following devaluation, it is important to know whether the additional volume of logs harvested since devaluation has resulted from the opening of more forest area to logging.

The area released by the forestry administration for logging has increased over the period from July 1991 to June 1996 (Table 16). However, it is not possible to conclude definitely that devaluation resulted in this increase, because the greatest change occurred before devaluation. In total, 1775000 ha of forest land were opened for logging as ventes de coupe during the five years preceding the study, about $72 \%$ of which were licensed to Cameroon nationals and $22 \%$ to foreigners.

The status of ventes de coupe gives only a partial picture of the forest area opened for logging, since there are also assièttes de coupe (or exploitation rights) which operate in former, but still active, licences (Table 17).

Despite the fact that data were not available for the years before devaluation, which prevents us from making conclusions about the effects of devaluation, the assièttes de coupe figures add another dimension of the study of the extent and distribution of logging rights in Cameroon. For three years 1993/94-1995/96, a total of 1942500 ha of forest land were granted to logging companies as assièttes de coupe. In contrast to the other type of logging rights, the assièttes de coupe were predominantly issued to foreigners (about 60\%). This can be explained by the fact that licences were granted to enterprises with processing units, and most of these enterprises are owned by foreign investors as shown (Tables 7 and 8).

Based on the number of assièttes de coupe and ventes de coupe, the total forest land area released for logging by the forestry administration between 1993 and 1996 can be estimated at 3222500 ha. However, the net area

Table 17. Assièttes de coupe (units of 2500 ha) opened for logging in Cameroon from 1993 to 1996

\begin{tabular}{|lcll|}
\hline Fiscal year & Domestic & Foreign & Total \\
\hline $1993 / 94$ & 76 & 170 & $\mathbf{2 4 6}$ \\
$1994 / 95$ & 95 & 138 & $\mathbf{2 3 3}$ \\
$1995 / 96$ & 141 & 157 & $\mathbf{2 9 8}$ \\
Total & $\mathbf{3 1 2}$ & $\mathbf{4 6 5}$ & $\mathbf{7 7 7}$ \\
\hline
\end{tabular}


logged would be far less since entrepreneurs do not always exploit the whole area granted to them in a given year. If the rights are not exhausted, the forestry department would renew the them the following year. Over the three years analysed 326 assièttes de coupe and 301 ventes de coupe were renewed, so that 1567 500 ha were counted twice. Therefore, the real forest area granted for logging in Cameroon between fiscal years $1993 / 94$ and $1995 / 96$ is estimated to be 1450 000 ha, or an average of 415000 ha per year. Cameroon nationals were granted 822500 ha over the three years, representing $56.7 \%$ of the total area opened. The proportion of the total area granted to Cameroon nationals appears to be inconsistent with the proportion of logs produced by them $(36 \%$; see Table $6)$. This anomaly can be explained by the high number of transactions between foreigners and nationals involved in logging, and not all these transactions are known by the forestry administration. Usually, Cameroon nationals may be granted logging rights by the administration but, because they do not have adequate experience, capital and equipment to perform field operations, they may sell or lease their rights to bigger and better-equipped enterprises of foreign investors. In addition, most foreigners have their logging rights in remote but timber-rich areas, where heavy equipment is required for logging.

\section{Species harvested and exported}

Based on the available lists of timber species harvested, as established by regional officers of the forestry department, it becomes apparent that the number of species has increased significantly during the three years following the devaluation of the CFA franc. From $1986 / 87$ to $1992 / 93$, the number of timber species exported from Cameroon fluctuated between 40 and 50. During the three years after devaluation, this number rose to 58,65 and 73 species successively.

Historically, the two most important timber species in Cameroon have been Ayous (Triplochiton scleroxylon) and Sapelli (Entandrophragma cylindricum). Ayous alone made up about $35 \%$ of the volume of timber products exported from Cameroon annually, and the two species together accounted for $55-60 \%$ of export volume. These are followed in importance by Azobe (Lophira alata), Iroko (Milicia excelsa) and Sipo (Entandrophroma utile). These five species together have traditionally constituted more than $75 \%$ of the timber product exports from Cameroon. Although they are still the most important quantitatively, their relative importance has declined since devaluation. Two other species, Fraké (Terminalia superba) and Tali (Erythrophleum ivorensis), have gained in importance. During 1994/95 and 1995/96, the seven species combined accounted for $75 \%$ of the volume of timber product exports. Furthermore, Fraké, which is a fast-growing tree species encountered in most forests of Cameroon, ranked third in 1995/96. The trend was maintained into the first semester of 1996/97. Fraké was not previously harvested in remote provinces of Cameroon because of its relatively low price per cubic metre which diminished the profit margin. However, its harvest is now seen as profitable by logging companies all over the country.

Both the increase in the total number of timber species and the decrease in the relative importance of the historically dominant species, suggest that there has been increasing diversification in timber species harvested in Cameroon since the devaluation of the CFA franc. This has resulted from a relative decrease in production costs (mainly transport cost) as compared to revenues earned from exports. In fact, after devaluation export revenues doubled while production costs increased by only about $34 \%$ due to inflation (Goreux 1996), thus increasing substantially the profit margins for export products. Therefore, some timber species which had low prices in export markets and historically were not harvested due to high production costs may now be harvested. This is especially true for Cameroon which had been identified as one of the Central African countries with the highest log transport costs prior to devaluation (Carret and Clément 1993). Thus, the devaluation of the CFA franc appears to have contributed to an increase in timber volume harvested per unit area of forest land. 


\section{CONCLUSIONS AND RECOMMENDATIONS}

With contributions of about $20 \%$ to the balance of payments (second largest) and 7\% to GDP, logging is now one of the most important industries within Cameroon's economy. Industrial timber harvesting, which in Cameroon involves mostly natural forests, has became a more attractive business since the start of the economic crisis in general and particularly since the devaluation of the CFA franc. Many Cameroon nationals have entered the logging industry. However, large foreign companies continue to dominate the industry because not only do they own most of the production and processing capacity, but they also have a better knowledge of the export market which consumes more than $70 \%$ of the logging industry production. To encourage more nationals to enter the business, the Cameroon government has made it easier for nationals to obtain logging rights. Easy access to logging rights may not be enough, however, as long as access to capital is still difficult and market information is poor. Furthermore, easy access to timber resources may threaten sustainability given that logging enterprises owned by nationals appear to be less stable in the business.

An important problem of the logging industry is the low level of processing capacity which results in export levels for raw logs far in excess of government targets, and reduces the contribution of the logging industry to the national economy. In addition to stronger enforcement of existing regulations, the Cameroon administration may consider stronger fiscal and financial incentives to promote the development of processing capacity.

From the analysis of information collected during this study, it is clear that the pressure on forest resources from industrial logging has increased since the devaluation of the CFA franc. More entrepreneurs have entered the logging industry, higher timber volume is harvested, the export market is flourishing and more land is opened each year to logging.

The average area opened for logging each year (415 $000 \mathrm{ha}$ ) and the current volume harvested and monitored $\left(2805000 \mathrm{~m}^{3}\right)$, imply a harvesting intensity of about $7 \mathrm{~m}^{3} / \mathrm{ha}$. Such a harvesting intensity is still low in comparison with other major tropical timber producer countries. Karsenty and Maitre (1994), for example, estimate that in Southeast Asia (Indonesia and Malaysia) the average harvest varies from $50-80 \mathrm{~m}^{3} / \mathrm{ha}$, and in Brazil from $10-20 \mathrm{~m}^{3} /$ ha. Therefore, in terms of harvesting intensity, it cannot be concluded that Cameroon forest are overlogged.

Combining the area annually opened for logging (415 $000 \mathrm{ha})$ and the total area planned as production forests (6 024608 ha) in the national Zoning Plan (Côté 1993), leads to the conclusion that, at the current pace, it might take only 15 years to log all the production forests. Such a cycle is certainly too short. The current extent of forest area opened for logging annually may constitute a threat to sustainable forest management. However, it should be emphasised that not all timber harvesting occurs within the permanent forest estate. In order to avoid problems in the future, careful planning and monitoring of forestry operations is necessary. The area to be opened for logging in each production forest should be carefully predetermined using the best available information on felling cycles.

Two important points should be kept in mind when using the results of this study.

- The Cameroon forestry sector is being restructured and the forestry institutions are changing, making it difficult to separate the effects of the devaluation from the effects of forest policy changes.

- In spite of the increase in timber resource utilisation there is little evidence that the current harvesting intensity is inconsistent with the goal of sustainable forest management. Some authors such as Carret and Clément (1993) have suggested that Cameroon's timber resources may have been underutilised in the past due to poor transport infrastructure. In any case, logging is still extensive and harvesting intensity remains below $10 \mathrm{~m}^{3} / \mathrm{h}$. The failure of forest resources to contribute to people's economic development in a developing country such as Cameroon may also give an incentive to convert forests to other types of land uses.

This study has focused on logging and devaluation, providing only a partial view of the forestry sector and its relationship to structural adjustment in Cameroon. A significantly more ambitious study would have been required to analyse changes that have affected the whole forestry sector since the implementation of the structural adjustment programme in Cameroon. One limitation of this study is imposed by the fact that monitoring of logging activities by the forestry administration in Cameroon is weak, so that statistics are not always recorded and archives not well maintained. Some figures given in this report are therefore rough estimates. Nevertheless, it is believed that the major trends have been portrayed correctly and that the study gives a reasonably accurate picture of the current status of Cameroon's logging industry. 


\section{REFERENCES}

Alibert, J. 1992 Le Cameroun à 1'heure de l'ajustement. Marchés Tropicaux, December 11: $3287-99$.

Allechi, M. and Niamkey, M. 1994 Evaluating the net gains from the CFA zone Membership: a different prospective. World Development 22: 1147-60.

Government of Cameroon. 1994 Loi no 94/01 du 20 janvier 1994 portant régime des forêts de la faune et de la pêche. Yaoundé, République du Cameroun.

Government of Cameroon. 1995 Décret no 95/531/PM du 23 août 1995 fixant modalités d'application du régime des forêts. Yaoundé, République du Cameroun.

MINEF (Ministry of Environment and Forestry). 1995 La politique forestière du Cameroun: document de politique générale. Ministry of Environment and Forestry. Yaoundé, République du Cameroun.

MINDIC (Ministry of Industrial and Commercial Development). 1996 Le commerce extérieur en chiffres. Ministère du Développement Industriel et Commercial. Yaoundé, République du Cameroun.

Carret, J. and Clement, J.C. 1993 La compétitivité des bois d'oeuvre africains. Ministère de la coopération. France.

Côté, S. 1993 Plan de zonage du Cameroun méridional. Prepared for the Ministry of Environment and Forestry by Poulin Thériault Inc., Quebec, Canada.

Crespi, J.M. 1994 The effect of a CFA Devaluation on tropical hardwood harvesting in equatorial Africa. Technical Paper, Colorado State University, USA.

Dongmo, M.R. 1996 Estimation des coéfficients de commercialisation et de transformation de quelques essences forestières exploitées par Cambois à Djoum. Mémoire de fin d'étude. Institut National de Developpement Rural, University of Dschang, Cameroon.

Goreux, L.M. 1996 Conjoncture Africaine: un premier bilan de la devaluation du franc CFA à fin décembre 1995 . Marchés Tropicaux, January 26: 152-3.

Horta, K. 1992 The growing threat to Central Africa's great forest. Environment: Annual Meeting News, Dakar '92. International Media Partners Publication.

Karsenty, A. and Maitre, H.F. 1994 L'exploitation et la gestion durable des forêts tropicales: pour de nouveaux outils de régulation. Bois et Fôrets des Tropiques 240: 37-52.

Kaimowitz, D., Thiele, G. and Pacheco, P. in press The effects of structural adjustment on deforestation and forest degradation in lowland Bolivia.

Kessler, J.J., Toornstra, F., Offermans, D., Verkuijl, H. and van Dorp, M. 1996 Structural adjustment and natural resources: the life support system under pressure. AIDEnvironment. Amsterdam, The Netherlands.

Monasinghe, M. and Cruz, W. 1994 Economywide policies in the environment: emerging lessons from experience. World Bank, Washington, DC.

Ngono, Z., Forni, E. and Jardin, J.L. 1994 Etude du redement au déroulage à l'usine de la SFID à Dimako. Projet Aménagement Pilote Intégré. Dimako, Cameroon.

Ntangsi, J. 1991 Structural adjustment in Cameroon and implications for Agriculture. Paper presented at the International Symposium on Agricultural Policy Analysis in Sub-Saharan Africa, Dschang University Center, Nov. 3-6.

Toornstra, F.H., Peresoon, G.A. and Youmbi, A. 1994 Deforestation in context: A Cameroon case study. AIDEnvironment, Amsterdam, The Netherlands.

Tchoungui, R., Gartland, S., Simo, M.J.A., Sikod, F., Youmbi, A., Ndjatsana, M. and Winpenny, J. 1995 Structural adjustment and sustainable development in Cameroon. A World Wide Fund for Nature Study. ODI, London, UK.

Vallée, O. 1988. La Banque mondiale et sa vision du Cameroun: Paper presented at the conference on "Political economy of Cameroon, historical perspectives", Leiden, The Netherlands, June 1-4. 
Verhagen, H. and Enthoven, C. 1993. Logging and conflicts in the rainforests of Cameroon. Report for Vereniging Milieudefensie and IUCN, Amsterdam, The Netherlands.

World Bank. 1990 Report on adjustment lending II: policies for the recovery of growth. World Bank, Washington, DC.

World Bank. 1994 Adjustment in Africa: reforms, results and the road ahead. Oxford University Press, Oxford, UK. 
ANNEX 1: Active logging enterprises of Cameroon

LITTORAL PROVINCE

\begin{tabular}{|c|c|c|}
\hline Company & Address & Ownership $^{\mathrm{a}}$ \\
\hline Yamba Paul & PO Box 50 Edea & $\mathrm{N}$ \\
\hline Wood \& Company & PO Box 2250 Dla & $\mathrm{F}$ \\
\hline WIJMA Dla & PO Box 1616 Dla & $\mathrm{F}$ \\
\hline West Forestry Company & PO Box 1804 Dla & $\mathrm{F}$ \\
\hline Union Forestière Camerounaise & PO Box 20 Dla & $\mathrm{N}$ \\
\hline Tchuisseu Mathieu & PO Box 11752 Dla & $\mathrm{N}$ \\
\hline Sté tropicale d'Exploita Forest & PO Box 1605 Dla & $\mathrm{F}$ \\
\hline Sté Transp Compl Ch. de Fer & PO Box Bonaberi Dla & $\mathrm{N}$ \\
\hline Sté Nouvelle Forestière & PO Box 681 Dla & $\mathrm{N}$ \\
\hline Sté Nouv. Forest. Sciage Camer. & PO Box 2037 Dla & $\mathrm{F}$ \\
\hline Sté Nationale Cam. Bois & PO Box 92 Dla & $\mathrm{F}$ \\
\hline Sté Ind. de Bois Africain & PO Box 376 Dla & $\mathrm{F}$ \\
\hline Sté Ind. Camer de Bois & PO Box 262 Nkongsamba & $\mathrm{N}$ \\
\hline Sté Forestière en Af. Centrale & PO Box 12332 & $\mathrm{~N}$ \\
\hline Sté Forestière de la Sanaga & PO Box 681 Dla & $\mathrm{F}$ \\
\hline Sté Forest. Ind. Lokoundjé & PO Box 1605 Dla & $\mathrm{F}$ \\
\hline Sté Forest. Ind. de la Sanaga & PO Box 1469 Dla & $\mathrm{F}$ \\
\hline Sté Forestière Hazim & PO Box 5908 Dla & $\mathrm{F}$ \\
\hline Sté Expl. Ind. du Camer & PO Box 209 Dla & $\mathrm{F}$ \\
\hline Sté des Forestiers du Camer. & PO Box 1632 Dla & $\mathrm{N}$ \\
\hline Sté d'Expl. Forest. de Magba & PO Box 910 Dla & $\mathrm{F}$ \\
\hline Sté d'Expl. Ind. Com. Agric. Forest. & PO Box 539 Dla & $\mathrm{N}$ \\
\hline Sté d’Expl. Forest. Agric. Camer. & PO Box 942 Dla & $\mathrm{F}$ \\
\hline Sté d’Epl. Bois du Camer. & PO Box 2064 Dla & $\mathrm{F}$ \\
\hline Sté Commerciale Indf. Bois & PO Box 1840 Dla & $\mathrm{N}$ \\
\hline Sté Camerounaise de Bois & PO Box 38 Dla & $\mathrm{N}$ \\
\hline Sté Camer. de Bois Ind. & PO Box 5060 Dla & $\mathrm{N}$ \\
\hline Sté Camer d'Expl. Forest. & PO Box 86 Edéa & $\mathrm{N}$ \\
\hline Sté Camer de Transf. de Bois & PO Box 77 Loum & $\mathrm{N}$ \\
\hline Sté Bois Tropicaux Africains & PO Box 12941 & $\mathrm{~F}$ \\
\hline Sté Bois de la Sanaga & PO Box 5786 Dla & $\mathrm{F}$ \\
\hline Sté Africaine de Bois de l'Est & PO Box 1810 Dla & $\mathrm{N}$ \\
\hline Strullou Daniel & PO Box 79 Dla & $\mathrm{F}$ \\
\hline Sté Forest Ind Com. Camer. & PO Box 589 Dla & $\mathrm{F}$ \\
\hline Sté Forest. Ind. du Wouri & PO Box 2851 Dla & $\mathrm{N}$ \\
\hline Sté Forest. Ind. de la Doumé & PO Box 1343 Dla & $\mathrm{N}$ \\
\hline Sté Forest. et des Sces du Camer & PO Box 8589 Dla & $\mathrm{N}$ \\
\hline Sté d'Expl. Forest. Ind. du Littorale & PO Box 4036 Dla & $\mathrm{N}$ \\
\hline Sté d'Expl. des Bois d'Afrique & PO Box 942 Dla & $\mathrm{F}$ \\
\hline Sté Camer Négoce Bois & PO Box 5344 Dla & $\mathrm{N}$ \\
\hline Sté Bois Tropicaux du Camer & PO Box 3766 Dla & $\mathrm{N}$ \\
\hline Songue Réné & PO Box 87 Edéa & $\mathrm{N}$ \\
\hline Sigala David & PO Box 64 Loum & $\mathrm{N}$ \\
\hline Propalm Bois & PO Box 5786 Dla & $\mathrm{F}$ \\
\hline Prenant \& Cie & PO Box 1772 Dla & $\mathrm{F}$ \\
\hline Njembe Jacques & PO Box 503 Edéa & $\mathrm{N}$ \\
\hline Nganga Emmanuel Henri & PO Box 580 Dla & $\mathrm{N}$ \\
\hline Nga Dieudonné Marie & PO Box 6807 Dla & $\mathrm{N}$ \\
\hline
\end{tabular}




\begin{tabular}{|llc|}
\hline Company & Address & Ownership \\
\hline Ndam Aboubakar Jean & PO Box 435 Dla & $\mathrm{N}$ \\
N. Georges & PO Box 4216 Dla & $\mathrm{N}$ \\
Moulet Boniface & PO Box 53 Dla & $\mathrm{N}$ \\
Monthe Sao Charles & PO Box 626 Dla & $\mathrm{N}$ \\
Minlend Michel & PO Box 240 Edéa & $\mathrm{N}$ \\
Location et Réparation Matériel & PO Box 1134 Dla & $\mathrm{N}$ \\
La logistique & PO Box 363 Edéa & $\mathrm{N}$ \\
La Forestière du Nkam & PO Box 85 Yabassi & $\mathrm{N}$ \\
La Côtière Forestière & PO Box 3187 Dla & $\mathrm{N}$ \\
Kieffer \& Cie & PO Box 260 Nkongsamba & $\mathrm{N}$ \\
Javardat Defor Belle Fleury & PO Box 5322 Dla & $\mathrm{F}$ \\
Grumes du Cameroun & PO Box 1959 Dla & $\mathrm{F}$ \\
Georges Demetriades & PO Box 3871 Dla & $\mathrm{F}$ \\
Forestière Est Cameroun & PO Box 59 Dla & $\mathrm{N}$ \\
Forestière de Campo & PO Box 1314 Dla & $\mathrm{F}$ \\
Expl. Grumes du Cameroun & PO Box 3592 Dla & $\mathrm{N}$ \\
Expl. Gle Produits Africains & PO Box 275 Dla & $\mathrm{N}$ \\
Etouman International LTD & PO Box 8670 Dla & $\mathrm{N}$ \\
Etoke Ebossé & PO Box 5100 Dla & $\mathrm{N}$ \\
Equato Bois & PO Box 3153 Dla & $\mathrm{N}$ \\
Ent. Forestière Camerounaise & PO Box 877 Dla & $\mathrm{F}$ \\
Ent. Com. Ind. du Camer. & PO Box 43 Mbanga & $\mathrm{N}$ \\
Engono Essame Emmanuel & PO Box 2196 Dla & $\mathrm{N}$ \\
Continental Agric. Camer. & PO Box 237 Edéa & $\mathrm{N}$ \\
Compagnie Ind. du Bois Camer & PO Box 3139 Dla & $\mathrm{N}$ \\
Compagnie Forest. Africaine & PO Box 976 Dla & $\mathrm{F}$ \\
COGIMEX Expl. Forest. & PO Box 1848 Dla & $\mathrm{N}$ \\
Cie Forest. Golf de Guinée & PO Box 703 Dla & $\mathrm{F}$ \\
Ceccaldi Paul & PO Box 912 Dla & $\mathrm{F}$ \\
Camwood & PO Box 2509 Dla & $\mathrm{N}$ \\
Camerounaise des Bois & PO Box 5989 Dla & $\mathrm{N}$ \\
Cameroon United Forest & PO Box 1652 Dla & $\mathrm{F}$ \\
Cameroon Industrial Forest. & PO Box 443 Dla & $\mathrm{F}$ \\
Camer. Timber \& Sce Co SARL & PO Box 4378 Dla & $\mathrm{N}$ \\
Bois et produits Forest. Camer & PO Box 5101 Dla \\
Alpi Pietro Fils Cameroun & PO Box 2130 Dla & $\mathrm{F}$ \\
Alhadji Bako Nagambo & PO Box 2234 Dla \\
Abega Jean Baptiste & PO Box 225 Dla & $\mathrm{N}$ \\
\hline
\end{tabular}


CENTRE PROVINCE

\begin{tabular}{|c|c|c|}
\hline Company & Address & Ownership $^{\mathrm{a}}$ \\
\hline Koury Paul & PO Box 1201 Yde & $\mathrm{F}$ \\
\hline Kome Lekeni & PO Box 871 Yde & $\mathrm{F}$ \\
\hline Forestière Agri. R. A. & PO Box $54 \mathrm{Yde}$ & $\mathrm{N}$ \\
\hline Ent. Forest. Ouambo & PO Box 141 Mbyo & $\mathrm{N}$ \\
\hline Cie Ind. Forest. de L'Ouest & PO Box 68 Yde & $\mathrm{F}$ \\
\hline Sté Forest Agri. Com & PO Box 24 Eseka & $\mathrm{N}$ \\
\hline Amougou Pierre & PO Box 2993 Yde & $\mathrm{N}$ \\
\hline Pallisco SARL & O Box 4171 Yde & $\mathrm{F}$ \\
\hline Nzongue Fréderic & PO Box 347 Yde & $\mathrm{N}$ \\
\hline EGTF RC Coron & PO Box 136 Yde & $\mathrm{F}$ \\
\hline Cameroon Timber LTD. & PO Box 1230 Yde & $\mathrm{N}$ \\
\hline Sté Forest. Ouest Cam. & PO Box 2335 Yde & $\mathrm{F}$ \\
\hline Sté Agri Forest. Kumba & PO Box 1877 Yde & $\mathrm{N}$ \\
\hline Sté. Expl. Forest. Eseka & PO Box 9 Eseka & $\mathrm{N}$ \\
\hline SOFIBEL & PO Box 1762 Belabo & $\mathrm{M}$ \\
\hline Yamakos G. & PO Box 127 Yde & $\mathrm{F}$ \\
\hline Sté. Forest. Du Nyong & PO Box 1732 Yde & $\mathrm{N}$ \\
\hline BOISCAM & PO Box 7350 Yde & $\mathrm{N}$ \\
\hline CAMWOOD & PO Box 182 Yde & $\mathrm{N}$ \\
\hline Bonanze Estate & PO Box 361 Yde & $\mathrm{N}$ \\
\hline SINTRABOIS & PO Box 84 Yde & $\mathrm{F}$ \\
\hline Nassif Albert & PO Box 438 Yde & $\mathrm{F}$ \\
\hline CELLUCAM & PO Box 423 Yde & $\mathrm{M}$ \\
\hline Continental Agricam & PO Box 4007 Yde & $\mathrm{N}$ \\
\hline Kedi Jean & PO Box 19 Mbyo & $\mathrm{N}$ \\
\hline Sté. Eploit. Forest. Thei & PO Box 1207 Yde & $\mathrm{N}$ \\
\hline Cie. Forest. Rika & PO Box 105 Yde & $\mathrm{F}$ \\
\hline Cameroon Fournit. Ind. & PO Box 1227 Yde & $\mathrm{N}$ \\
\hline GRUMCAM & PO Box 4027 Yde & $\mathrm{F}$ \\
\hline Groupement Afr. Distribut. & PO Box 4700 Yde & $\mathrm{N}$ \\
\hline SAB & PO Box 89 Yde & $\mathrm{F}$ \\
\hline SABE & PO Box 68 Yde & $\mathrm{N}$ \\
\hline Cie Camer. De la Ngoko & PO Box 1283 Yde & $\mathrm{F}$ \\
\hline Sté. Bois du Cameroun. & PO Box 37 Eseka & $\mathrm{F}$ \\
\hline COCIF & PO Box 1207 Yde & $\mathrm{N}$ \\
\hline SEFC & PO Box 141 Mbyo & $\mathrm{N}$ \\
\hline Sté. Générale du Sud & PO Box 99 Eseka & $\mathrm{N}$ \\
\hline Assiga Mvogo & PO Box 5019 Yde & $\mathrm{N}$ \\
\hline SCIB & PO Box 6363 Yde & $\mathrm{N}$ \\
\hline Sté. Forest. Freres Camer. & PO Box 1184 Yde & $\mathrm{N}$ \\
\hline SCEB & PO Box 8238 Yde & $\mathrm{N}$ \\
\hline Simplex Cameroun & PO Box 5509 Yde & $\mathrm{N}$ \\
\hline ECAM Placage & PO Box 76 Mbyo & $\mathrm{M}$ \\
\hline SEPFC & PO Box 6214 Yde & $\mathrm{N}$ \\
\hline Forestière Camerounaise & PO Box 55 Yde & $\mathrm{N}$ \\
\hline Eko Ebongue F. & PO Box 6346 Yde & $\mathrm{N}$ \\
\hline Expl. Forest Ind Ndelele & PO Box 2372 Yde & $\mathrm{N}$ \\
\hline Camerounaise Bois Brut & PO Box 1877 Yde & $\mathrm{N}$ \\
\hline Owona Amougou Luc M. & PO Box 292 Yde & $\mathrm{N}$ \\
\hline
\end{tabular}




\begin{tabular}{|c|c|c|}
\hline Company & Address & Ownership $^{\mathrm{a}}$ \\
\hline Ro. Trade Industry & PO Box 4592 Yde & $\mathrm{N}$ \\
\hline Kelle Wood & PO Box 326 Yde & $\mathrm{N}$ \\
\hline Eyia Pierre & PO Box 10037 Yde & $\mathrm{N}$ \\
\hline Manga Michel M. D. & PO Box 1723 Yde & $\mathrm{N}$ \\
\hline Mvongo Nde P. & PO Box 1588 Yde & $\mathrm{N}$ \\
\hline SCIEB & PO Box 11359 Yde & $\mathrm{N}$ \\
\hline SABM & PO Box 326 Yde & $\mathrm{N}$ \\
\hline Cie Forest. Camer. & PO Box 5880 Yde & $\mathrm{N}$ \\
\hline Inter Travaux & PO Box 6884 Yde & $\mathrm{N}$ \\
\hline Mponengang R. & PO Box 332 Mbyo & $\mathrm{N}$ \\
\hline Atemengue Nzie A. & PO Box 6455 Yde & $\mathrm{N}$ \\
\hline Bois Tropicaux Camer. & PO Box 1326 Yde & $\mathrm{N}$ \\
\hline Owona Elara C. & PO Box 599 Yde & $\mathrm{N}$ \\
\hline Sté Bois d'Afrique S. A. & PO Box 11084 Yde & $\mathrm{N}$ \\
\hline Liboz L.R. & PO Box 136 Yde & $\mathrm{N}$ \\
\hline Paraluc Sarl & PO Box 11588 Yde & $\mathrm{N}$ \\
\hline Mme Peiffer Kese C. & PO Box 211 Eseka & $\mathrm{N}$ \\
\hline Nanga C. D. & PO Box 3010 Yde & $\mathrm{N}$ \\
\hline Cie Forest. de l'Est & PO Box 3177 Yde & $\mathrm{F}$ \\
\hline Amougou Aboui & PO Box 248 Yde & $\mathrm{N}$ \\
\hline Sté. Forest. Com et Sce & PO Box 6912 Yde & $\mathrm{N}$ \\
\hline Mme Eboué Doris & PO Box 89 Yde & $\mathrm{N}$ \\
\hline Ekobena S. N. & PO Box 1141 Yde & $\mathrm{N}$ \\
\hline Grabess & PO Box 4058 Yde & $\mathrm{N}$ \\
\hline Ngbwa Obam Jean & PO Box 7215 Yde & $\mathrm{N}$ \\
\hline Sté. Forest. des Tech. Camer & PO Box 6622 Yde & $\mathrm{N}$ \\
\hline Expl. Engoulou Aboutou & PO Box 79 Nanga Eboko & $\mathrm{N}$ \\
\hline Sté. Forest. Ngog Mapubi & PO Box 15 Ngog Mapub & $\mathrm{N}$ \\
\hline African Wood & PO Box 1539 Yde & $\mathrm{N}$ \\
\hline Sté. Camer. De Bois & PO Box 5262 Yde & $\mathrm{N}$ \\
\hline Tsimi J. M. & PO Box 4949 Yde & $\mathrm{N}$ \\
\hline Medou Njemba R. & PO Box 13453 Yde & $\mathrm{N}$ \\
\hline Ndongo R. & PO Box 8151 Yde & $\mathrm{N}$ \\
\hline Sté Forest. Enguele \& Fils & PO Box 41 Mbyo & $\mathrm{N}$ \\
\hline Sté. Etude \& Tranf. Forest & PO Box 4597 Yde & $\mathrm{N}$ \\
\hline Toukam Marcel \& Cie & PO Box 228 Mbyo & $\mathrm{N}$ \\
\hline Sté. Forest Nasser \& Fils & PO Box 1940 Yde & $\mathrm{N}$ \\
\hline Khoury Miguel & PO Box 326 Yde & $\mathrm{F}$ \\
\hline Sté. Camer. de Transp. Electr. M. & PO Box 20038 Yde & $\mathrm{N}$ \\
\hline S. N. COCAM & PO Box 154 Mbyo & $\mathrm{E}$ \\
\hline Njong E. N. & PO Box 11504 Yde & $\mathrm{N}$ \\
\hline La Filière Bois & PO Box 13840 Yde & $\mathrm{N}$ \\
\hline Sté Forest. Ngo Maben & PO Box 1487 Yde & $\mathrm{N}$ \\
\hline La Gle de L'informatiq. \& Expl. & PO Box 1174 Yde & $\mathrm{N}$ \\
\hline Essene Nkou & PO Box 5653 Yde & $\mathrm{N}$ \\
\hline Owona Owona Isidore & PO Box 228 Mbyo & $\mathrm{N}$ \\
\hline Sté Bois d'Afrique & PO Box 10103 Yde & $\mathrm{N}$ \\
\hline
\end{tabular}




\section{SOUTHWEST PROVINCE}

\begin{tabular}{|lll|}
\hline Company & Address & Ownership $^{\mathrm{a}}$ \\
\hline Akem Valentine Peter & PO Box 2 Kumba & $\mathrm{N}$ \\
Farm Ind. \& Forest. Ent. & PO Box 125 Kumba & $\mathrm{N}$ \\
Timber Ind. Cameroon Ltd. & PO Box 173 Kumba & $\mathrm{M}$ \\
Mukete Plantation Ltd. & PO Box 1 Kumba & $\mathrm{N}$ \\
Ste Nwangum Sons Const. Ltd. & PO Box 59 Kumba & $\mathrm{N}$ \\
Sté Ind. Camer. Forestière & PO Box 21 Limbe & $\mathrm{F}$ \\
Susan \& Sammy Commercial Timber & PO Box 423 Kumba & $\mathrm{N}$ \\
Cameroon Development Corporation & PO Box Limbe & $\mathrm{M}$ \\
Zangim Albert & PO Box 48 Buea & $\mathrm{N}$ \\
Fako Timber Co. Ltd. & PO Box 17 Kumba & $\mathrm{N}$ \\
Cameroon Agric. Forest expl. Co & PO Box 81 Kumba & $\mathrm{N}$ \\
Sté. Camer de 1'Ind. \& du Commerce & PO Box 532 Limbe & $\mathrm{N}$ \\
\hline
\end{tabular}

SOUTH PROVINCE

\begin{tabular}{|llc|}
\hline Company & Address & Ownership $^{\mathrm{a}}$ \\
\hline Mengue Nkili \& Fils & PO Box 24 Zoétélé & $\mathrm{N}$ \\
Sté Ind. Bois MJP \& Frères & PO Box 307 Sangmelima & $\mathrm{N}$ \\
SFDL & PO 172 Sangmelima & $\mathrm{N}$ \\
Sté Forestière de la Lobé & PO Box 237 Kribi & $\mathrm{N}$ \\
Sté Commerciale du Dja \& Lobo & PO Box 64 Sangmelima & $\mathrm{N}$ \\
Rouillon \& Fils & PO Box 108 Kribi & $\mathrm{F}$ \\
Parquet Moulu Res. Cameroun & PO Box 172 Sangmelima & $\mathrm{F}$ \\
Ntoutoumou Jacques Roger & PO Box 226 Kribi & $\mathrm{N}$ \\
Moïse Ayolo 1 Fils & PO Box 249 Sangmelima & $\mathrm{N}$ \\
Karayannis Dimitros N. & PO Box 100 Ebolowa & $\mathrm{F}$ \\
Etys Kritikos & PO Box 53 Kribi & $\mathrm{F}$ \\
Descar Serge Germain & PO Box 167 Kribi & $\mathrm{F}$ \\
Compagnie Forestière Kritikos & PO Box 53 Kribi & $\mathrm{F}$ \\
Bois Hydrolique Cameroun & PO Box 7 Kribi & $\mathrm{F}$ \\
Bekol Cameroun & PO Box 33 Kribi & $\mathrm{F}$ \\
\hline
\end{tabular}

EAST PROVINCE

\begin{tabular}{|llc|}
\hline Company & Address & Ownership $^{\mathrm{a}}$ \\
\hline Forestière de product \& Expl. des Essences & PO Box 88 Bertoua & $\mathrm{N}$ \\
Sté Camer \& Forest. Industrielle & PO Box 29 Bertoua & $\mathrm{N}$ \\
Sté Camer et Entreprises Réunies & PO Box 64 Belabo & $\mathrm{N}$ \\
Sté Forestière Doumé Dimako & PO Box 227 Bertoua & $\mathrm{N}$ \\
Sté Forestière Industrielle Mbethem & PO Box 155 Bertoua & $\mathrm{N}$ \\
& & \\
\hline
\end{tabular}


WEST PROVINCE

\begin{tabular}{|llc|}
\hline Company & Address & Ownership $^{\mathrm{a}}$ \\
\hline Sté d'Expl. Forest. du Haut Nkam & PO Box 263 Bafang & $\mathrm{N}$ \\
Petit Guyot Bernard & PO Box 8 Magba & $\mathrm{N}$ \\
S.E.F.N. Massangam & PO Box 103 Foumbot & $\mathrm{N}$ \\
SCTCB Bafoussam & PO Box 746 Bafoussam & $\mathrm{N}$ \\
Sté Poteaux Bois SONEL & PO Box Bafoussam & $\mathrm{M}$ \\
\hline
\end{tabular}

Note: ${ }^{\mathrm{a}} \mathrm{N}=$ Domestic, $\mathrm{F}=$ Foreign, $\mathrm{M}=$ joint venture 
ANNEX 2: Field survey questionnaire

1 - Company:

2 - Date of establishment:

3 - Shareholders (Names and number of shares)

Licences $\left(\mathrm{N}^{\circ} \&\right.$ area $)$

\section{4 - Main components}

- Logging department

- Sawmill

YES

NO

- Veneer mil

YES

NO

- Plywood

YES

NO

- Matches

YES

NO

- Matches

YES

NO

\section{5 - History (Major changes since the foundation of the company)}

5a - Changes in the Company ownership (shareholders):

$5 \mathrm{~b}$ - Changes in the Company main products:

$5 \mathrm{c}$ - Changes in the Company capacity:

$5 \mathrm{~d}$ - Changes in the infrastructures and location

\section{6 - Personnel}

6a - Full time

- Executives nationals :

- Executives expatriates:

- Supervisors nationals:

- Supervisors expatriates:

- Labourers nationals:

- Labourers expatriates: 
$6 \mathrm{~b}$ - Part time

- Executives nationals:

- Executives expatriates:

- Supervisors nationals:

- Supervisors expatriates:

- Labourers nationals:

- Labourers expatriates:

$6 \mathrm{c}-$ Changes in personnel over the times:

If possible, report on changes in personnel number since 1985:

\section{7 - Firm capacity}

$7 \mathrm{a}-$ Log production $\left(\mathrm{m}^{3}\right)$

\begin{tabular}{|cc|}
\hline YEARS & VOLUMES $\left(\mathrm{m}^{3}\right)$ \\
\hline $1996 / 1997$ & \\
$1995 / 1996$ & \\
$1994 / 1995$ & \\
$1993 / 1994$ & \\
$1992 / 1993$ & \\
$1991 / 1992$ & \\
$1990 / 1991$ & \\
$1989 / 1990$ & \\
$1988 / 1989$ & \\
$1987 / 1988$ & \\
$1986 / 1987$ & \\
$1995 / 1986$ & \\
\hline
\end{tabular}

$7 \mathrm{c}-$ Veneer production

\begin{tabular}{|ll|}
\hline YEARS & VOLUMES $\left(\mathrm{m}^{3}\right)$ \\
\hline $1996 / 1997$ & \\
$1995 / 1996$ & \\
$1994 / 1995$ & \\
$1993 / 1994$ & \\
$1992 / 1993$ & \\
$1991 / 1992$ & \\
$1990 / 1991$ & \\
$1989 / 1990$ & \\
$1988 / 1989$ & \\
$1987 / 1988$ & \\
$1986 / 1987$ & \\
$1995 / 1986$ & \\
\hline
\end{tabular}

$7 \mathrm{~b}$ - Production of sawnwood

\begin{tabular}{|ll|}
\hline YEARS & VOLUMES $\left(\mathrm{m}^{3}\right)$ \\
\hline $1996 / 1997$ & \\
$1995 / 1996$ & \\
$1994 / 1995$ & \\
$1993 / 1994$ & \\
$1992 / 1993$ & \\
$1991 / 1992$ & \\
$1990 / 1991$ & \\
$1989 / 1990$ & \\
$1988 / 1989$ & \\
$1987 / 1988$ & \\
$1986 / 1987$ & \\
$1995 / 1986$ & \\
\hline
\end{tabular}

7d - Plywood

\begin{tabular}{|ll|}
\hline YEARS & VOLUMES $\left(\mathrm{m}^{3}\right)$ \\
\hline $1996 / 1997$ & \\
$1995 / 1996$ & \\
$1994 / 1995$ & \\
$1993 / 1994$ & \\
$1992 / 1993$ & \\
$1991 / 1992$ & \\
$1990 / 1991$ & \\
$1989 / 1990$ & \\
$1988 / 1989$ & \\
$1987 / 1988$ & \\
$1986 / 1987$ & \\
$1995 / 1986$ & \\
\hline
\end{tabular}


7e - Other industrial wood products

\begin{tabular}{|ll|}
\hline YEARS & VOLUMES $\left(\mathrm{m}^{3}\right)$ \\
\hline $1996 / 1997$ \\
$1995 / 1996$ \\
$1994 / 1995$ \\
$1993 / 1994$ \\
$1992 / 1993$ \\
$1991 / 1992$ \\
$1990 / 1991$ \\
$1989 / 1990$ \\
$1988 / 1989$ \\
$1987 / 1988$ \\
$1986 / 1987$ \\
$1995 / 1986$
\end{tabular}

\section{8 - Species harvested}

List of the species harvested each year since 1985:

\section{9 - Marketing}

National market

\begin{tabular}{|lll|}
\hline Year & Type of product & quantity \\
\hline $1996 / 1997$ & \\
$1995 / 1996$ & \\
$1994 / 1995$ & \\
$1993 / 1994$ & \\
$1992 / 1993$ & \\
$1991 / 1992$ & \\
$1990 / 1991$ & \\
$1989 / 1990$ & \\
$1988 / 1989$ & \\
$1987 / 1988$ & \\
$1986 / 1987$ & \\
$1985 / 1986$ & \\
\hline
\end{tabular}

Export

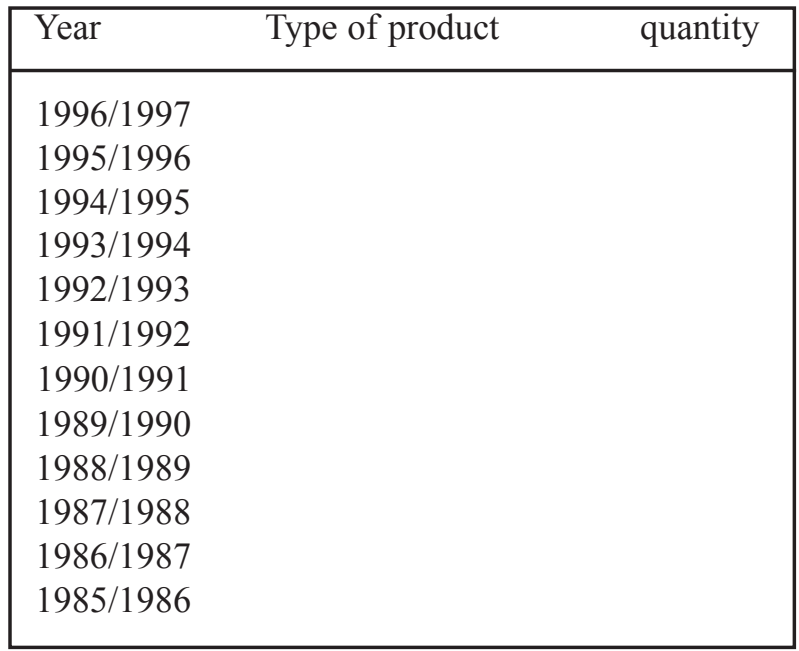


ANNEX 3: List of surveyors (students) and supervisors by province

\begin{tabular}{|c|c|c|c|}
\hline Province & Supervisor & Students & Period (month) \\
\hline Centre & Amougou Samuel & $\begin{array}{l}\text { Bidoung Bidoung } \\
\text { Nkoulou Jervais } \\
\text { Nna Théodores } \\
\text { Akono Kabeyene }\end{array}$ & 2 \\
\hline East & Nguele Tolo D. & Mpayinka Nkinda F. & 1 \\
\hline Littoral & Bengono Belinga & $\begin{array}{l}\text { Ngum Francis } \\
\text { Nkou Ayissi } \\
\text { NdiNdi Joseph } \\
\text { Mandeng Charlotte }\end{array}$ & 2 \\
\hline West & Ondja'a Mendoula G. & Ndengue Akam G. & 1 \\
\hline South & Abessolo Ako'o & Sama Solange & 2 \\
\hline South-West & Ndibi Blaise P. & $\begin{array}{l}\text { Mbock Vincent } \\
\text { Ngum Geraldine }\end{array}$ & 1 \\
\hline & Total: 6 & Total: 13 & \\
\hline
\end{tabular}


ANNEX 4: Logging enterprises in the sample

\begin{tabular}{|c|c|c|c|c|}
\hline Enterprise & $\begin{array}{c}\text { Number of }{ }^{\mathrm{a}} \\
\text { Components }^{\mathrm{a}}\end{array}$ & $\begin{array}{c}\text { Log production } \\
\mathrm{m}^{3}\end{array}$ & Exports & Ownership $^{b}$ \\
\hline $\mathrm{HFC}$ & 2 & 172973.416 & 59565.957 & $\mathrm{~F}$ \\
\hline PRENANT Cie & 2 & 99141.394 & 54605.411 & $\mathrm{~F}$ \\
\hline SIGALA & 1 & 1260.955 & 51703.000 & $\mathrm{~N}$ \\
\hline SEBC & 2 & 150602.533 & 49538.033 & $\mathrm{~F}$ \\
\hline SIBAF & 2 & 165659.354 & 42957.069 & $\mathrm{~F}$ \\
\hline SDG & 2 & 2448.365 & 3108.690 & $\mathrm{~N}$ \\
\hline SFID & 4 & 175629.454 & 40796.000 & $\mathrm{~F}$ \\
\hline CAMBOIS & 2 & 38283.000 & & $\mathrm{~N}$ \\
\hline SOCATHAI & 4 & 20842.382 & 20842.382 & $\mathrm{~F}$ \\
\hline ZanguimA & 1 & 9934.561 & 20788.000 & $\mathrm{~N}$ \\
\hline EGTC RC Coron & 2 & 44721.603 & 19662.000 & $\mathrm{~F}$ \\
\hline SEBAC & 1 & 90058.322 & 19566.545 & $\mathrm{~F}$ \\
\hline SOCAMER & 1 & 6548.213 & 6548.213 & $\mathrm{~N}$ \\
\hline STCCF & 2 & 106122.808 & 2938.685 & $\mathrm{~N}$ \\
\hline SABM & 2 & 36149.284 & 18645.000 & $\mathrm{~F}$ \\
\hline PALLISCO sarl & 2 & 39502.926 & 17459.711 & $\mathrm{~F}$ \\
\hline GWZ & 2 & 63963.574 & 15937.977 & F \\
\hline SFDL & 2 & 283.268 & 5435.804 & $\mathrm{~N}$ \\
\hline CFE & 2 & 69547.839 & 2221.407 & $\mathrm{~N}$ \\
\hline SFIL & 2 & 32286.389 & 14151.024 & $\mathrm{~F}$ \\
\hline $\mathrm{SNC}$ & 2 & 6502.568 & 1848.000 & M \\
\hline SFH & 2 & 119524.138 & 1441.000 & $\mathrm{~F}$ \\
\hline SEFN & 2 & 48180.699 & 12724.000 & $\mathrm{~N}$ \\
\hline SOTREF & 2 & 71518.136 & 12511.991 & $\mathrm{~F}$ \\
\hline SIBM & 2 & 8016.766 & 12000.000 & $\mathrm{~N}$ \\
\hline MEDOU \& Fils & 1 & 2063.604 & 1300.976 & $\mathrm{~N}$ \\
\hline NJR & 1 & 1261.149 & 786.320 & $\mathrm{~N}$ \\
\hline CAFECO & 1 & 9152.107 & 9152.107 & $\mathrm{~N}$ \\
\hline TCHUISSEU JM & 1 & 9060.152 & 633.000 & $\mathrm{~N}$ \\
\hline SNF & 1 & 41050.752 & 552.466 & M \\
\hline KARAYANNIS & 2 & 8350.654 & 535.678 & F \\
\hline FM & 1 & 5456.530 & 461.000 & $\mathrm{~N}$ \\
\hline SEFAC & 2 & 72714.076 & 34.776 & F \\
\hline LOREMA & 2 & 29.153 & 13.330 & $\mathrm{~N}$ \\
\hline EFOM & 1 & 11.490 & 11.940 & $\mathrm{~N}$ \\
\hline DEFOMBELE & 1 & 6440.849 & 4325.000 & $\mathrm{~N}$ \\
\hline SOCIB & 2 & 25000.000 & 11.059 & $\mathrm{~N}$ \\
\hline ALPICAM & 4 & 58031.108 & 8640.807 & $\mathrm{~F}$ \\
\hline SFS & 1 & 11420.091 & & $\mathrm{~F}$ \\
\hline KHOURY M. & 2 & 9957.043 & & $\mathrm{~F}$ \\
\hline KHOURY P. & 2 & 5589.554 & & $\mathrm{~F}$ \\
\hline
\end{tabular}




\begin{tabular}{|c|c|c|c|c|}
\hline Enterprise & $\begin{array}{l}\text { Number of }{ }^{\mathrm{a}} \\
\text { Components }\end{array}$ & $\begin{array}{c}\text { Log production } \\
\mathrm{m}^{3}\end{array}$ & Exports & Ownership $^{b}$ \\
\hline GRABESS & 1 & 2142.182 & & $\mathrm{~F}$ \\
\hline SEFMA & 1 & 3488.152 & & M \\
\hline ECIC & 1 & 53870.996 & & $\mathrm{~N}$ \\
\hline $\mathrm{COK}$ & 2 & 4155.890 & 7834.043 & $\mathrm{~F}$ \\
\hline LBE & 2 & 20819.556 & & $\mathrm{~N}$ \\
\hline IBC & 1 & 17000.000 & & $\mathrm{~N}$ \\
\hline MINLEND M. & 1 & 32607.242 & 4009.000 & $\mathrm{~N}$ \\
\hline SOCODJAL & 1 & 11036.184 & & $\mathrm{~N}$ \\
\hline MAF & 1 & 10306.537 & & $\mathrm{~N}$ \\
\hline SCTB & 1 & 9823.513 & & $\mathrm{~N}$ \\
\hline SONGUE R. & 2 & 7823.513 & & $\mathrm{~N}$ \\
\hline SFCS & 2 & 7447.250 & & $\mathrm{~N}$ \\
\hline JON & 1 & 7105.049 & & $\mathrm{~N}$ \\
\hline COFA & 1 & 5830.159 & & $\mathrm{~N}$ \\
\hline AVEICO & 1 & 5480.912 & & $\mathrm{~N}$ \\
\hline NDM & 1 & 5164.701 & & $\mathrm{~N}$ \\
\hline EYIA P. & 2 & 4337.300 & & $\mathrm{~N}$ \\
\hline Elanga M. & 1 & 4051.805 & & $\mathrm{~N}$ \\
\hline SEFT & 2 & 3517.331 & & $\mathrm{~N}$ \\
\hline SCTCB & 1 & 3431.119 & & $\mathrm{~N}$ \\
\hline EEE & 1 & 2613.348 & 7132.497 & $\mathrm{~N}$ \\
\hline N Georges & 1 & 3330.682 & & $\mathrm{~N}$ \\
\hline ELMA & 1 & 3251.936 & & $\mathrm{~N}$ \\
\hline CUF & 1 & 2898.124 & & $\mathrm{~N}$ \\
\hline $\mathrm{ZA}$ & 1 & 2740.040 & & $\mathrm{~N}$ \\
\hline SOCAFOR & 1 & 2720.911 & & $\mathrm{~N}$ \\
\hline MR & 1 & 2577.428 & & $\mathrm{~N}$ \\
\hline MVONGO NDE & 1 & 2224.390 & & $\mathrm{~N}$ \\
\hline NDONGO R. & 1 & 1880.417 & & $\mathrm{~N}$ \\
\hline KODIMA & 1 & 1584.837 & & $\mathrm{~N}$ \\
\hline LFIS & 1 & 1282.952 & & $\mathrm{~N}$ \\
\hline EMD & 1 & 1260.955 & & $\mathrm{~N}$ \\
\hline SICAB & 1 & 1148.731 & & $\mathrm{~N}$ \\
\hline NTOUTOUM J. & 1 & 551.524 & & $\mathrm{~N}$ \\
\hline BOIS-CAM & 1 & 332.885 & & $\mathrm{~N}$ \\
\hline SOCIB & 1 & 32438.662 & 3826.342 & $\mathrm{~F}$ \\
\hline SEFPCO & 1 & 296.146 & & $\mathrm{~N}$ \\
\hline SEFEN & 1 & 287.997 & & $\mathrm{~N}$ \\
\hline CAMWOOD & 1 & 240.594 & & $\mathrm{~N}$ \\
\hline
\end{tabular}

Notes: a 1 = timber harvesting alone, 2 = timber harvesting and sawmill, 4 = timber harvesting, sawmill, rotary veneer mill, plywood factory.

b $\mathrm{F}=$ Foreign, $\mathrm{N}=$ Domestic, $\mathrm{M}=$ Joint venture 
ANNEX 5: Entreprises comprising timber processing units in Cameroon

\begin{tabular}{|c|c|c|c|c|}
\hline Name & Type $^{a}$ & Capacity $\left(\mathrm{m}^{3}\right)$ & Location & Ownership $^{b}$ \\
\hline ALPICAM & SC-P-CP & 120000 & LITTORAL & $\mathrm{F}$ \\
\hline BEKOL & $\mathrm{SC}$ & 20000 & SOUTH & $\mathrm{N}$ \\
\hline OTAC & $\mathrm{SC}$ & 50000 & EAST & $\mathrm{N}$ \\
\hline BTA & $\mathrm{SC}$ & 30000 & LITTORAL & $\mathrm{F}$ \\
\hline CAFOREX & $\mathrm{SC}$ & 24000 & CENTRE & $\mathrm{N}$ \\
\hline CFE & $\mathrm{SC}$ & 36000 & EAST & $\mathrm{F}$ \\
\hline CFK & $\mathrm{SC}$ & 14400 & SOUTH & M \\
\hline $\mathrm{CIF}$ & $\mathrm{SC}$ & 10000 & LITTORAL & $\mathrm{N}$ \\
\hline CIFOA/SABE & $\mathrm{SC}$ & 36000 & CENTRE & $\mathrm{N}$ \\
\hline DESIGN & $\mathrm{SC}$ & 12000 & LITTORAL & $\mathrm{F}$ \\
\hline DN KARYA & $\mathrm{SC}$ & 24000 & SOUTH & $\mathrm{F}$ \\
\hline ECAM & $\mathrm{P}$ & 24000 & CENTRE & M \\
\hline EFK & $\mathrm{SC}$ & 10000 & EAST & $\mathrm{N}$ \\
\hline EFMK & $\mathrm{SC}$ & 48000 & CENTRE & $\mathrm{F}$ \\
\hline EFMK & $\mathrm{SC}$ & 36000 & CENTRE & $\mathrm{F}$ \\
\hline GDE SCIERIE & $\mathrm{SC}$ & 10000 & LITTORAL & $\mathrm{N}$ \\
\hline GRUMCAM & $\mathrm{SC}$ & 60000 & EAST & $\mathrm{F}$ \\
\hline GWZ & $\mathrm{SC}$ & 50000 & SOUTH & $\mathrm{F}$ \\
\hline HFC & $\mathrm{SC}$ & 60000 & SOUTH & $\mathrm{F}$ \\
\hline IBC & $\mathrm{SC}$ & 36000 & CENTRE & M \\
\hline IBCAM & $\mathrm{P}$ & 36000 & LITTORAL & $\mathrm{F}$ \\
\hline KIENKE & $\mathrm{SC}$ & 24000 & EAST & $\mathrm{N}$ \\
\hline MADEX & $\mathrm{SC}$ & 34000 & EAST & $\mathrm{F}$ \\
\hline PRENANT & $\mathrm{SC}$ & 48000 & EAST & $\mathrm{F}$ \\
\hline RC Coron & $\mathrm{SC}$ & 48000 & CENTRE & $\mathrm{F}$ \\
\hline SAB & $\mathrm{SC}$ & 50000 & CENTRE & $\mathrm{F}$ \\
\hline SABM & $\mathrm{SC}$ & 36000 & CENTRE & $\mathrm{F}$ \\
\hline SCTCB & $\mathrm{SC}$ & 24000 & WEST & $\mathrm{N}$ \\
\hline SEBC & $\mathrm{SC}$ & 108000 & EAST & $\mathrm{F}$ \\
\hline SEFAC & $\mathrm{SC}$ & 10000 & EAST & $\mathrm{F}$ \\
\hline SEFE & $\mathrm{SC}$ & 36000 & CENTRE & $\mathrm{N}$ \\
\hline SEFN & $\mathrm{SC}$ & 45000 & WEST & M \\
\hline SFDL & $\mathrm{SC}$ & 5000 & SOUTH & $\mathrm{N}$ \\
\hline SFHS & $\mathrm{SC}$ & 45000 & LITTORAL & $\mathrm{F}$ \\
\hline SFHSNT & $\mathrm{SC}$ & 36000 & CENTRE & $\mathrm{F}$ \\
\hline SFID & SC-P-CP & 168000 & EAST & $\mathrm{F}$ \\
\hline SFIL & $\mathrm{SC}$ & 50000 & EAST & $\mathrm{F}$ \\
\hline SIB & $\mathrm{SC}$ & 10000 & EAST & $\mathrm{N}$ \\
\hline SIBAF & $\mathrm{SC}$ & 60000 & EAST & $\mathrm{F}$ \\
\hline SIBM & $\mathrm{SC}$ & 24000 & SOUTH & $\mathrm{N}$ \\
\hline SICAB & $\mathrm{SC}$ & 12000 & LITTORAL & $\mathrm{N}$ \\
\hline SID & $\mathrm{SC}$ & 36000 & SOUTH & $\mathrm{F}$ \\
\hline SINTRABOIS & $\mathrm{SC}$ & 24000 & CENTRE & $\mathrm{F}$ \\
\hline
\end{tabular}




\begin{tabular}{|c|c|c|c|c|}
\hline Name & Type $^{a}$ & $\overline{\text { Capacity }\left(\mathrm{m}^{3}\right)}$ & Location & Ownership $^{\mathrm{b}}$ \\
\hline SNCOCAM & SC-P-CP & 72000 & CENTRE & M \\
\hline SOCAFI & $\mathrm{SC}$ & 10000 & EAST & $\mathrm{N}$ \\
\hline SOFIBEL & SC-P-CP & 60000 & EAST & $\mathrm{F}$ \\
\hline SOGENIC & $\mathrm{SC}$ & 18000 & LITTORAL & $\mathrm{N}$ \\
\hline SONGUE & $\mathrm{SC}$ & 17300 & LITTORAL & $\mathrm{N}$ \\
\hline SOTRANSCOFER & SC & 20400 & LITTORAL & $\mathrm{N}$ \\
\hline SOTREF & $\mathrm{SC}$ & 50000 & EAST & $\mathrm{F}$ \\
\hline STBK & $\mathrm{SC}$ & 24000 & EAST & $\mathrm{N}$ \\
\hline TIC/SDG & $\mathrm{SC}$ & 30000 & LITTORAL & $\mathrm{N}$ \\
\hline UNALOR & $\mathrm{D}$ & 7000 & LITTORAL & $\mathrm{N}$ \\
\hline
\end{tabular}

\section{Total Capacity 1988100}

Notes: a $\mathrm{SC}=$ Sawmill, $\mathrm{P}=$ Veneer mill (rotary or sliced), $\mathrm{CP}=$ Plywood factory

b $\mathrm{N}=$ Domestic, $\mathrm{F}=$ Foreign, $\mathrm{M}=$ Joint venture 
ANNEX 6: Enterprises involved in timber harvesting

\begin{tabular}{|c|c|c|c|}
\hline Enterprise & Ownershipa & Enterprise & Ownershipa \\
\hline Abega JB & $\mathrm{N}$ & Intertravaux & $\mathrm{N}$ \\
\hline ALPICAM & $\mathrm{F}$ & JAN & $\mathrm{N}$ \\
\hline Assiga MF & $\mathrm{N}$ & KARAYANNIS & $\mathrm{F}$ \\
\hline AVEICO & $\mathrm{N}$ & Kedi Jean & $\mathrm{N}$ \\
\hline BEKOL & $\mathrm{N}$ & Kelle wood & $\mathrm{N}$ \\
\hline BIZOU & M & KhouryM & $\mathrm{F}$ \\
\hline BTA & M & KhouryP & $\mathrm{F}$ \\
\hline BTC & $\mathrm{N}$ & KODIMA & M \\
\hline CAFECO & $\mathrm{N}$ & LBA & $\mathrm{N}$ \\
\hline Camwood & M & LFIS & $\mathrm{N}$ \\
\hline CFE & M & LOREMA & $\mathrm{N}$ \\
\hline CIBC & $\mathrm{N}$ & MAF & $\mathrm{N}$ \\
\hline CIC & $\mathrm{N}$ & MangaM & $\mathrm{N}$ \\
\hline COCAM & M & MBELLEY F & $\mathrm{N}$ \\
\hline COFA & $\mathrm{N}$ & Medou \& Fils & $\mathrm{N}$ \\
\hline CONAC & $\mathrm{N}$ & MESSI MBARGA & $\mathrm{N}$ \\
\hline Coron & M & MINLEND. J & $\mathrm{N}$ \\
\hline Coupes illégales & & MPL & $\mathrm{N}$ \\
\hline CUF & M & Mponengang R & $\mathrm{N}$ \\
\hline Defombele & $\mathrm{N}$ & Mvongo N & $\mathrm{N}$ \\
\hline Demitriades G & $\mathrm{F}$ & N Georges & $\mathrm{F}$ \\
\hline ECAM PLACAGE & $\mathrm{F}$ & NDONGO R & $\mathrm{N}$ \\
\hline ECIC & $\mathrm{N}$ & NGA DM & $\mathrm{N}$ \\
\hline EEE & $\mathrm{N}$ & NGBWA OJ & $\mathrm{N}$ \\
\hline EFAA & $\mathrm{N}$ & NJR & $\mathrm{N}$ \\
\hline EFAN & $\mathrm{N}$ & NTOUTOUMOU JC & $\mathrm{N}$ \\
\hline EFAP & $\mathrm{N}$ & PALLISCO & M \\
\hline EFFAM & $\mathrm{N}$ & PARALUC & $\mathrm{N}$ \\
\hline EFIN & $\mathrm{N}$ & PRENANT & $\mathrm{F}$ \\
\hline EFOAC & $\mathrm{N}$ & Récupérations & \\
\hline ELMA & $\mathrm{N}$ & $\mathrm{SAB}$ & \\
\hline EMD & $\mathrm{N}$ & SABE & $\mathrm{F}$ \\
\hline EQUATO BOIS & $\mathrm{N}$ & SABM & M \\
\hline ETS NICOLE & $\mathrm{N}$ & SCIB & $\mathrm{N}$ \\
\hline EYIA P & $\mathrm{N}$ & SCIEB & $\mathrm{N}$ \\
\hline Fako Timber & $\mathrm{N}$ & SCTB & $\mathrm{N}$ \\
\hline FODDI & $\mathrm{N}$ & SEBAC & $\mathrm{F}$ \\
\hline Forest. Camer & $\mathrm{N}$ & SEBC & $\mathrm{F}$ \\
\hline Forest. Moloundou & $\mathrm{F}$ & SEFAC & $\mathrm{F}$ \\
\hline Forestiere Cam & $\mathrm{N}$ & SEFE & $\mathrm{N}$ \\
\hline GAD & $\mathrm{N}$ & SEFIL & $\mathrm{N}$ \\
\hline GRABESS & M & SEFMA & $\mathrm{N}$ \\
\hline GRUMCAM & $\mathrm{F}$ & SEFN & $\mathrm{N}$ \\
\hline GRUMEX & M & SEICAFCO & $\mathrm{N}$ \\
\hline HFC & $\mathrm{F}$ & SEPFCO & \\
\hline Interbois & M & SFCS & \\
\hline SFDL & $\mathrm{N}$ & Soffca & $\mathrm{N}$ \\
\hline
\end{tabular}




\begin{tabular}{|lclc|}
\hline Enterprise & Ownershipa $^{\mathbf{a}}$ & Enterprise & Ownership $^{\mathbf{a}}$ \\
\hline SFH & $\mathrm{M}$ & SOGENIC & $\mathrm{N}$ \\
SFID & $\mathrm{F}$ & SONGUE R & $\mathrm{N}$ \\
SFIL & $\mathrm{M}$ & SOTRANSCOFER & $\mathrm{N}$ \\
SFNM & $\mathrm{N}$ & SOTREF & $\mathrm{F}$ \\
SFS & $\mathrm{F}$ & STBK & $\mathrm{N}$ \\
SFSC & $\mathrm{M}$ & StéBoiscam & $\mathrm{N}$ \\
SIBAF & $\mathrm{F}$ & STFC & $\mathrm{N}$ \\
SIBM & $\mathrm{N}$ & TCHUISSEU M & $\mathrm{N}$ \\
SICAB & $\mathrm{N}$ & UNALOR & $\mathrm{M}$ \\
Sigala D & $\mathrm{N}$ & UNIVERSAL T Co. & $\mathrm{N}$ \\
SNF & $\mathrm{N}$ & West wood ent & $\mathrm{N}$ \\
SOCAFI & $\mathrm{N}$ & WIJMA & $\mathrm{F}$ \\
SOCAFOR & $\mathrm{N}$ & YOMBA P & $\mathrm{N}$ \\
SOCAMER & $\mathrm{N}$ & ZANGUIM A & $\mathrm{N}$ \\
SOCIB & $\mathrm{N}$ & & \\
SOFEN & $\mathrm{N}$ & & \\
\hline
\end{tabular}

Notes: a $\mathrm{N}=$ Domestic, $\mathrm{F}=$ Foreign, $\mathrm{M}=$ Joint venture 
ANNEX 7: Timber product exporting enterprises of Cameroon

\begin{tabular}{|lcll|}
\hline Enterprise & Ownership $^{\mathrm{a}}$ & Enterprise & Ownership $^{\mathrm{a}}$ \\
\hline SOLET & $\mathrm{N}$ & & \\
SFID & $\mathrm{F}$ & SID & $\mathrm{F}$ \\
SAB & $\mathrm{F}$ & ECAM PLACAGE & $\mathrm{F}$ \\
SIBAF & $\mathrm{F}$ & BTA & $\mathrm{F}$ \\
SEBC & $\mathrm{F}$ & DNK & $\mathrm{F}$ \\
CORON & $\mathrm{F}$ & SFHSNT & $\mathrm{F}$ \\
J PRENANT & $\mathrm{F}$ & EFF & $\mathrm{F}$ \\
SEBAC & $\mathrm{F}$ & PROPALM & $\mathrm{F}$ \\
SN COCAM & $\mathrm{M}$ & SOTREF & $\mathrm{F}$ \\
BSC & $\mathrm{N}$ & HFC & $\mathrm{F}$ \\
CAMBOIS & $\mathrm{N}$ & SABM & $\mathrm{F}$ \\
STCCF & $\mathrm{N}$ & SFIIL & $\mathrm{F}$ \\
SOFACAM & $\mathrm{F}$ & Filière Bois & $\mathrm{N}$ \\
COK & $\mathrm{F}$ & AVEICO & $\mathrm{N}$ \\
ONY BROS & $\mathrm{F}$ & SBTC & $\mathrm{N}$ \\
ALPICAM & $\mathrm{F}$ & SCIEB & $\mathrm{N}$ \\
SOFIT & $\mathrm{F}$ & EFPK & $\mathrm{N}$ \\
CFE & $\mathrm{F}$ & SIAMBOISEIC & $\mathrm{N}$ \\
GRUMCAM & $\mathrm{F}$ & EMO & $\mathrm{N}$ \\
R PALLISCO & $\mathrm{F}$ & WETCOMPANY & $\mathrm{N}$ \\
WIJMA & $\mathrm{F}$ & Jeanne Shopping & $\mathrm{N}$ \\
SEFAC & $\mathrm{F}$ & CONAC & $\mathrm{N}$ \\
SEFN & $\mathrm{M}$ & B.Z. & $\mathrm{N}$ \\
CIBC & $\mathrm{M}$ & JFF & $\mathrm{N}$ \\
Z.A. & $\mathrm{N}$ & EYIA P & $\mathrm{N}$ \\
SETRAF & $\mathrm{N}$ & CAFOREX & $\mathrm{N}$ \\
SIDEM & $\mathrm{N}$ & SOMIEPRIC & $\mathrm{N}$ \\
SFIW & $\mathrm{N}$ & SOCOPAN & $\mathrm{N}$ \\
SIGALA & $\mathrm{N}$ & SOFIT & $\mathrm{N}$ \\
& & & \\
\hline
\end{tabular}

Notes: a $\mathrm{N}=$ Domestic, $\mathrm{F}=$ Foreign, $\mathrm{M}=$ Joint venture 